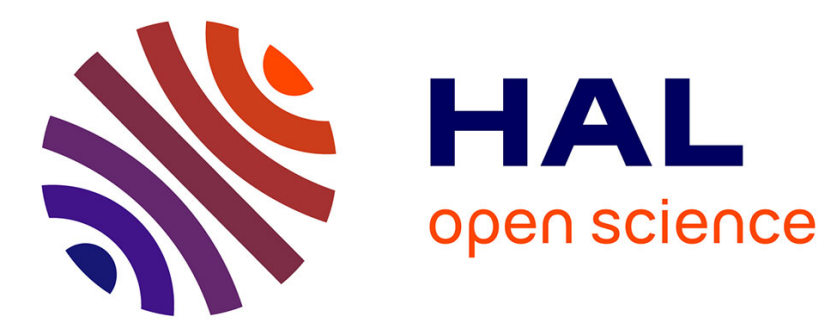

\title{
Holocene fire regime changes from multiple-site sedimentary charcoal analyses in the Lourdes basin (Pyrenees, France)
}

\author{
Damien Rius, Boris Vannière, Didier Galop, Hervé Richard
}

\section{To cite this version:}

Damien Rius, Boris Vannière, Didier Galop, Hervé Richard. Holocene fire regime changes from multiple-site sedimentary charcoal analyses in the Lourdes basin (Pyrenees, France). Quaternary Science Reviews, 2011, 30 (13-14), pp.1696-1709. 10.1016/j.quascirev.2011.03.014 . hal-00649514

\author{
HAL Id: hal-00649514 \\ https://hal.science/hal-00649514
}

Submitted on 21 Apr 2017

HAL is a multi-disciplinary open access archive for the deposit and dissemination of scientific research documents, whether they are published or not. The documents may come from teaching and research institutions in France or abroad, or from public or private research centers.
L'archive ouverte pluridisciplinaire HAL, est destinée au dépôt et à la diffusion de documents scientifiques de niveau recherche, publiés ou non, émanant des établissements d'enseignement et de recherche français ou étrangers, des laboratoires publics ou privés. 


\title{
Holocene fire regime changes from multiple-site sedimentary charcoal analyses in the Lourdes basin (Pyrenees, France)
}

\author{
Damien Rius ${ }^{\mathrm{a} b \mathrm{~b}, *}$, Boris Vannière ${ }^{\mathrm{a}}$, Didier Galop ${ }^{\mathrm{b}}$, Hervé Richard ${ }^{\mathrm{a}}$ \\ a Laboratoire Chrono-Environnement, UMR 6249 CNRS, Université de Franche-Comté, UFR ST, 16 route de Gray, 25030 Besançon, France \\ ${ }^{\mathrm{b}}$ Laboratoire GEODE, UMR 5602 CNRS, Université Toulouse II-le Mirail, 5 allées Antonio Machado, 31058 Toulouse, France
}

\section{A R T I C L E I N F O}

\section{Article history:}

Received 23 November 2010

Received in revised form

20 March 2011

Accepted 25 March 2011

Available online 13 May 2011

\section{Keywords:}

Macrocharcoal

Fire regime

Climate

Human impact

Holocene

Pyrenees

\begin{abstract}
A B S T R A C T
One lake and three peat bogs from the Lourdes glacial basin (France) were used for macrocharcoal analyses and fire frequency reconstruction over the entire Holocene (11700 years). The chronology was based upon thirty-three $14 \mathrm{C}$ AMS dates. Comparison of the distribution of both CHarcoal Accumulation Rate (CHAR) and fire return intervals showed that charcoal accumulation significantly differs between the lake and the peat bogs, but that frequency calculation overcomes the disparity between these site types. A composite frequency was built from the four individual records to assess regional versus local variability and fire regime controls by comparisons with regional fire activity, Holocene climatic oscillations and vegetation history. The millennial variability can be depicted as follows: relatively high frequency between 8000 and 5000 cal a BP (up to 5 fires/500 yrs), relatively low frequency between 5000 and $3000 \mathrm{cal}$ a BP (down to 0 fires/500 yrs), and an increase between 3000 and $500 \mathrm{cal}$ a BP (up to 4 fires/500 yrs). From 8000 to $5000 \mathrm{cal}$ a BP, fire frequency displays strong synchrony between sites and appears to be mostly driven by increased summer temperature characterizing the Holocene Thermal Maximum (HTM). On the contrary, during the last 3000 years fire frequency was heterogeneous between sites and most probably human-driven. However, higher frequency at the millennial scale during the mid-Holocene strongly suggests that the perception of human-driven fire regime depends on the strength of natural controls.
\end{abstract}

(c) 2011 Elsevier Ltd. All rights reserved.

\section{Introduction}

Fire is both a natural phenomenon and a human tool, used for example to clear and maintain open agro-pastoral areas since the Early Neolithic at least (Kaland, 1986; Tinner et al., 2005; Colombaroli et al., 2008). It is still used in Europe as a landscape management tool in grazed areas (Buffière et al., 1995; Ribet, 2009). Recent studies from the Alps, the Pyrenees and the Mediterranean area show that millennial variability in Holocene fire regimes is linked to climatic oscillations, particularly for the early to midHolocene (11700-5000 cal a BP; Vannière et al., 2011), but also that fire regimes are human-driven during the last 3000-4000 years (Tinner et al., 2005; Rius et al., 2009; Vannière et al., 2010). Thus, it appears difficult to understand human impact on fire regimes without placing it in the context of Holocene climatic and vegetation changes. Quantification of fire frequency from

\footnotetext{
* Corresponding author. Laboratoire Chrono-Environment, UMR 6249 CNRS-UFC 16 route de Gray F-25030 Besançon Cedex, France. Tel.: +33 381666 395/255; fax: +33381666568 .

E-mail address: damien.rius@univ-fcomte.fr (D. Rius).
}

sedimentary macrocharcoal is a relevant method to study human impact on ecosystems throughout the Holocene (Conedera et al., 2009). However, this method is spatio-temporally limited (Olsson et al., 2010) and requires high resolution analysis. A second issue concerns the spatial significance of the results and of multi-proxy data comparison: what is the relevant scale of fire frequency reconstruction?

Theroretical and empirical efforts have been made to quantify charcoal production from biomass burning, both natural and anthropogenic (Fearnside et al., 2001; Eckmeier et al., 2007), and charcoal transport both during a fire (Clark et al., 1998; Pisaric, 2002; Lynch et al., 2004; Tinner et al., 2006; Higuera et al., 2007; Peters and Higuera, 2007) and after a fire (Whitlock and Millspaugh, 1996; Blackford, 2000; Ohlson and Tryterud, 2000). Comparing the results of those studies shows that experimental slash-and-burn for agro-pastoral purposes may produce more charcoal than experimental wildfire due to differences in fire intensity and severity, but there is no data about transport during the agro-pastoral fire experiments.

Experimental and natural wildfire studies show a considerable variability in the distance that macrocharcoal $(>150 \mu \mathrm{m})$ is 
transported ranging from $80 \mathrm{~m}$ or less (Clark et al., 1998; Lynch et al., 2004) to $5 \mathrm{~km}$ (Tinner et al., 2006) and even $20 \mathrm{~km}$ (Pisaric, 2002). Theoretical work (Higuera et al., 2007; Peters and Higuera, 2007) demonstrated that macrocharcoal analysis is relevant at the local scale, ie $500 \mathrm{~m}-1 \mathrm{~km}$ around the coring site because longdistance transport does not dampen the strong relationship between local fires and their sedimentary macrocharcoal signature. However, those studies were mainly focused on North American boreal forests where natural fire events are potentially severe (crown fires). In any case, those ecosystems were weakly impacted by agricultural activity prior to relatively recent European settlement (Marlon et al., 2008).

The reproducibility of microcharcoal $(<30 \mu \mathrm{m})$ analyses between mires has already been successfully tested (Innes et al., 2004). Regional, large-scale controlled fire activity deduced from microcharcoal might be consistently recorded at a very fine-scale in some cases. Nonetheless, it is unclear how representative a fire history from a single site is, both spatially and temporally. Multisite macrocharcoal analysis conducted in an area which exceeds each site's charcoal source area may enable the assessment of whether or not large-scale fire history (mostly controlled by climate and vegetation change) is recorded at the local scale, and if so from which point anthropogenic fire-use blurred such a relationship.

In this paper, we compare charcoal records from three peat bogs and a lake in the Lourdes glacial basin (France). The aim was to examine synchronicity from secular to millennial scales and between-sites variability as a function of site type (peat bog/lake) and size. We also synthesise the inferred fire frequency from the four analyzed records as a composite to assess regional fire activity and local variability. Finally, we discuss the pattern of fire frequency in terms of potential controls.

\section{Material and methods}

\subsection{Study area}

The surroundings of Lourdes $\left(43^{\circ} 3^{\prime} 53^{\prime \prime} \mathrm{N}, 0^{\circ} 02^{\prime} 44^{\prime \prime} \mathrm{W}\right)$ have a complex geomorphologic structure of glacial origin. The "Gave de Pau" glacier originated in the axial part of the Pyrenean range (Fig. 1), $52 \mathrm{~km}$ south, and had its terminal basin in the actual location of Lourdes. At its maximum extent (45-50 ka BP, Mardones and Jalut, 1983; Herail et al., 1986; Reille and Andrieu, 1995) it was divided into five glacial branches from the west to the east (Fig. 1): 1) directed westwards the first one is where the actual "Gave de Pau" river course is (ca 350m asl) 2) the second one above, also directed westwards, is occupied by Lake Lourdes and Lourdes peatbog at its western shore, 3 ) the third glacial tongue was oriented northwest and is occupied by the palaeolake of "Biscaye", whose peaty valley is now colonized by deciduous forest, 4 ) the fourth one was headed northeast and was partly filled by the palaeolake of "le Monge" whose peat bog is now covered by a commercial zone, 5) and the last one was headed eastwards.

Three of the coring sites are located in piedmont glacial depressions: Biscaye peat bog, Lake Lourdes, and Lourdes peat bog, but the depression of Lake Lourdes and peat bog is perched in a small catchment. The fourth one is another peat bog of glacial origin: the "col d'Ech" peat bog $(710 \mathrm{~m}$ asl) which is located south above Lake Lourdes. The three peat bogs are raised, ombrotrophic bogs where charcoal input is mainly atmospheric (Clark and Patterson, 1997) with no fire related sedimentation as reported by Buckman et al. (2009). The main characteristics of the sites and distance between coring points are indicated in Table 1 .

The Lourdes basin is at the limit of the western and central Pyrenees under temperate oceanic influence: mean annual precipitation of $1200 \mathrm{~mm}$ with maxima during Autumn and Spring, mean annual temperature is $12.5^{\circ} \mathrm{C}$ (Mean summer $\mathrm{T}^{\circ}=19$ and Mean winter $\mathrm{T}^{\circ}=6{ }^{\circ} \mathrm{C}, 1931-2006$, MeteoFrance Data). Regional vegetation consists of Atlantic-type oak forest mainly dominated by Quercus (Q. robur and Q. pyrenaica) with Corylus and Betula. The north-facing slopes (below $900 \mathrm{~m}$ ) are covered by a mixed beech-oak forest, which is the dominant vegetation type of the bioclimatic stage in the area. The col d'Ech peat bog has slightly different environmental settings that the three other sites : it is located under a $900 \mathrm{~m}$ high south-facing calcareous slope. The strong shelter effect from this slope results in the presence of Q. pubescens and some Buxus sempervirens stands.

In the contemporary environment, there are two fire seasons in the central Pyrenees. The main one in extent (January, February, March) and number of occurrences, is winter, during which fires are linked to pasture management. The second one is summer (July, August) and features both anthropogenic and natural (lightning) fires (Préfecture des Hautes-Pyrénées, 2007).

\subsection{Coring, sedimentology and chronology}

The three peat bog cores were mechanically taken (APAGEO device) with a Russian peat sampler (GIK type, $100 \mathrm{~cm}$ long, $10 \mathrm{~cm}$ in diameter) which avoided sediments compaction. Lake Lourdes was cored with an Uwitec platform with a $3 \mathrm{~m}$ long and $6.3 \mathrm{~cm}$ in diameter piston corer.

The chronology for this study was derived from thirty-three $14 \mathrm{C}$ AMS radiocarbon dates (Table 2). For the peat records, bulk sediments were dated after removing rootlets, because the high organic content enabled us to do so without reservoir effect (Blaauw et al., 2004). Charcoal was dated for the lacustrine record in order to avoid hard-water effect. Calibration to year cal. BP was made using CALIB software (Stuiver and Reimer, 1993) version 6.1.0., based on the data set IntCal09 (Reimer et al., 2009). Dates are expressed as intercepts with $2 \sigma$ range (Table 2 ). To predict ages along the entire profile, we used mixed-effect modeling according to the procedure standardized by Heegaard et al. (2005), except for Lourdes peat bog because of too few dates $(n=5)$. Indeed, the mixed-effect-model encompassed only three of five radiocarbon dates (calibration ranges at $2 \sigma$ ). We then used a cubic spline with the most linear interpolation possible that best fitted the calibration ranges. We estimated the $95 \%$ confidence interval following a similar procedure to the other depth-age models (Heegaard et al., 2005). One date was rejected (in italic in Table 2) in Lake Lourdes. The measure was not robust because of low carbon content in the dated sample and it yields an inverted date with regard to its stratigraphic position (Table 2).

\subsection{Macroscopic charcoal analysis}

Contiguous samples of $2.6 \mathrm{~cm}^{3}$ were retrieved with a needleless syringe at every $\mathrm{cm}$ of the core, soaked in a $10 \% \mathrm{NaOH}$ solution during $24 \mathrm{~h}$ for peat disaggregation, then in a $6 \% \mathrm{H}_{2} \mathrm{O}_{2}$ solution during the same time to bleach non-charcoal organic material and thus make charcoal identification easier (Rhodes, 1998). As we aimed to reconstruct local fire history, charred particle were isolated using wet sieving (Carcaillet et al., 2001; Whitlock and Larsen, 2001) with a $150 \mu \mathrm{m}$ mesh size (Clark, 1988; Ohlson and Tryterud, 2000). Charcoal identification was restricted to the criteria usually defined in literature (Umbanhowar and McGrath, 1998; Enache and Cumming, 2006). Both charcoal particles number and area concentrations were estimated under a binocular microscope at a $50 \times$ magnification with a reticule grid of $10 \times 10$ squares of $62.510^{-3} \mathrm{~mm}^{2}$ each. Ten increasing size classes were defined $(31.25-62.5,62.5-125, \ldots$, $\left.187.5-25010-3 \mathrm{~mm}^{2}, \ldots\right)$. Charcoal concentration $\left(\mathrm{mm}^{2} \mathrm{~cm}^{-3}\right)$ was 

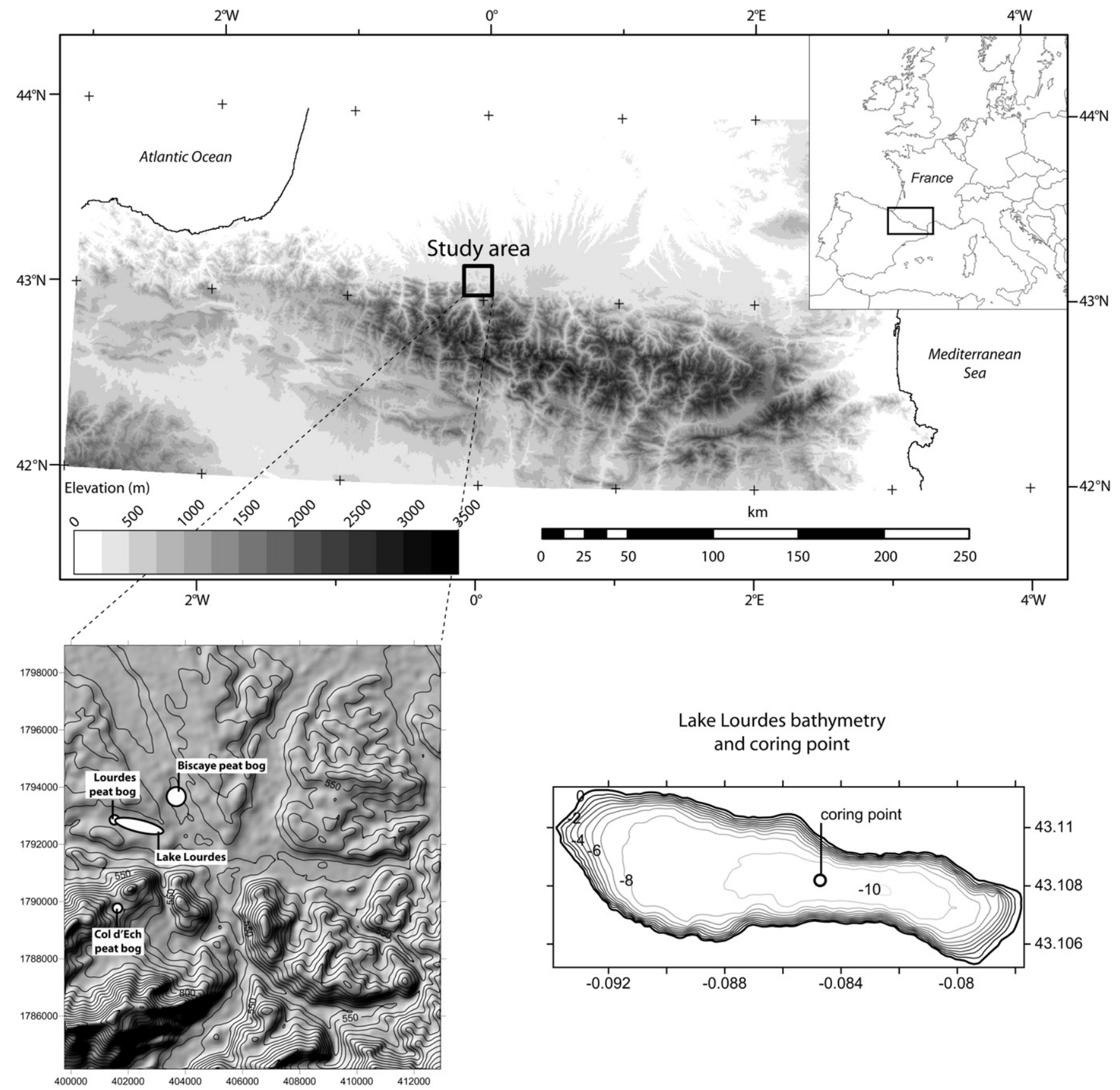

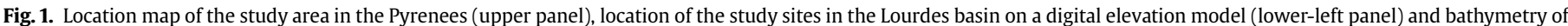

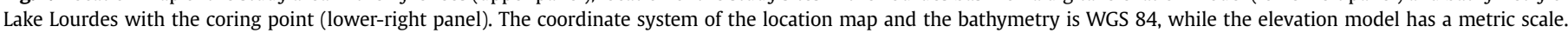

expressed as CHarcoal Accumulation Rate (CHAR, $\mathrm{mm}^{2} \mathrm{~cm}^{-2} \mathrm{yr}^{-1}$ ) based on sedimentation rate estimated by the depth-age model.

Charcoal analyses were focused on different chronological windows as follows: the whole Holocene section was analyzed on Lake Lourdes because it has the best temporal resolution (mean $=15$, median $=12$ years $\mathrm{cm}^{-1}$ ) as we aimed to obtain the most detailed reference record possible for the area. Lourdes peat bog was analyzed for the last 4000 years because it appeared to have the best temporal resolution for this period according to Reille and Andrieu (1995) results. Biscaye peat bog was analyzed for the last 6500 years in order to draw comparison over the mid-Holocene with the other sites. According to the previous study (Reille and Andrieu, 1995), the late Holocene seemed to have a poorer resolution in this record. Ech peat bog was separately analyzed for a previous study.

\subsection{Between sites variability in charcoal accumulation}

Charcoal transport is generally limited to a range between $80 \mathrm{~m}$ and $1 \mathrm{~km}$, with some potential for long-distance transport (Lynch et al., 2004; Higuera et al., 2007). Therefore, the potential variability between charcoal accumulation and fire frequency at Lourdes peat bog and Lake Lourdes in particular cannot be accounted for only by transport patterns. Potential discrepancies or leads and lags should be then explained by: 1) random natural variability and noise (sampling, analysis, dating) which is not a totally manageable 
Table 1

Environmental settings of study sites.

\begin{tabular}{|c|c|c|c|c|}
\hline Site name & Lourdes peat bog & Lake Lourdes & Biscaye peat bog & Ech peat bog \\
\hline Latitude & $43^{\circ} 06^{\prime} 28^{\prime \prime} \mathrm{N}$ & $43^{\circ} 06^{\prime} 38^{\prime \prime} \mathrm{N}$ & $43^{\circ} 07^{\prime} 09^{\prime \prime} \mathrm{N}$ & $43^{\circ} 4^{\prime} 56^{\prime \prime} \mathrm{N}$ \\
\hline Longitude & $0^{\circ} 05^{\prime} 01^{\prime \prime} \mathrm{W}$ & $0^{\circ} 05^{\prime} 45 \mathrm{~W}$ & $0^{\circ} 04^{\prime} 16^{\prime \prime} \mathrm{W}$ & $0^{\circ} 5^{\prime} 34^{\prime \prime} \mathrm{W}$ \\
\hline Type & Peat (palaeolake) & Lake & Peat (palaeolake) & Peat (palaeolake) \\
\hline Elevation (m. asl) & 430 & 430 & 410 & 710 \\
\hline Lake/peat area & 17 ha & 44 ha & $?$ & 5.3 \\
\hline Inlet/outlet, stream draining the peat bog & None & No/yes & Yes & None \\
\hline Water depth & $\mathrm{x}$ & $11 \mathrm{~m}$ & $\mathrm{x}$ & $\mathrm{x}$ \\
\hline Core length/analysed section length (cm) & $1050 / 300$ & $1200 / 720$ & $700 / 350$ & $550 / 370$ \\
\hline Mean deposition time $(\mathrm{yrs} / \mathrm{cm})$ & 13.5 & 15 & 20 & 25 \\
\hline \multicolumn{5}{|l|}{ Distance between coring points $(\mathrm{km})$} \\
\hline Lourdes peat bog & $\mathrm{x}$ & 1.05 & 2.4 & 3.06 \\
\hline Lake Lourdes & 1.05 & $\mathrm{x}$ & 1.65 & 2.86 \\
\hline Biscaye & 2.4 & 1.65 & $\mathrm{x}$ & 4.4 \\
\hline Ech peat bog & 3.06 & 2.86 & 4.4 & $\mathrm{x}$ \\
\hline
\end{tabular}

bias; 2) basin type and size which determine the Potential Source Charcoal Area -PCSA, Higuera et al., (2007); 3) sedimentary patterns and deposition rate in particular, 4) fire within the studied site itself (peatland fire).

Ech peat bog is isolated from the three other study sites (Table 1). This would suggest difference from the three other sites because it is located $400 \mathrm{~m}$ higher and $3 \mathrm{~km}$ away, with a slightly different vegetation context, shelter effects, and was probably impacted by different land use.

First, we wanted to assess the correlation between charcoal accumulation rates and sedimentary patterns at each site. Pearson's

Table 2

AMS-radiocarbon dates from the Lourdes basin measured by the Poznan radiocarbon laboratory, Poland.

\begin{tabular}{|c|c|c|c|c|}
\hline $\begin{array}{l}\text { Sample name } \\
\text { and depth } \\
(\mathrm{cm})\end{array}$ & Lab.code & Type & $\begin{array}{l}\text { AMS radiocarbon } \\
\text { date } \mathrm{BP}\end{array}$ & $\begin{array}{l}\text { Cal. yr BP }[2 \sigma \\
\text { range] probability } \\
\text { area }\end{array}$ \\
\hline \multicolumn{5}{|c|}{ Biscaye peat bog } \\
\hline Bis 0719.5 & Poz-35436 & Peat & $1660 \pm 30$ & $1422-1691$ \\
\hline Bis 0760.5 & Poz-35437 & Peat & $3180 \pm 35$ & $3351-3466$ \\
\hline Bis 07109.5 & Poz-34147 & Peat & $3825 \pm 35$ & $4094-4406$ \\
\hline Bis 07169.5 & Poz-34145 & Peat & $4450 \pm 40$ & $4882-4934$ \\
\hline Bis 07209.5 & Poz-34149 & Peat & $4830 \pm 30$ & $5476-5647$ \\
\hline Bis 07269.5 & Poz-34148 & Peat & $5340 \pm 40$ & $5992-6276$ \\
\hline Bis 07331.5 & Poz-35438 & Peat & $5820 \pm 40$ & $6503-6730$ \\
\hline \multicolumn{5}{|l|}{ Ech peat bog } \\
\hline Ech 0620.5 & Poz-23135 & Peat & $645 \pm 30$ & $555-668$ \\
\hline Ech 0646.5 & Poz-23136 & Peat & $1210 \pm 30$ & $1059-1256$ \\
\hline Ech 06105.5 & Poz-20009 & Peat & $2770 \pm 30$ & $2788-2946$ \\
\hline Ech 06145.5 & Poz-23137 & Peat & $3615 \pm 35$ & $3836-4071$ \\
\hline Ech 06190.5 & Poz-23138 & Peat & $4550 \pm 40$ & $5049-5434$ \\
\hline Ech 06228.5 & Poz-23139 & Peat & $5090 \pm 40$ & $5743-5917$ \\
\hline Ech 06287.5 & Poz-23140 & Peat & $6420 \pm 40$ & $7274-7422$ \\
\hline Ech 06329.5 & Poz-23141 & Peat & $7340 \pm 50$ & $8019-8308$ \\
\hline Ech 06380.5 & Poz-27285 & Bulk & $9890 \pm 50$ & $11202-11597$ \\
\hline \multicolumn{5}{|c|}{ Lourdes peat bog } \\
\hline Lrd 0649.5 & Poz-35414 & Peat & $235 \pm 30$ & $1-422$ \\
\hline Lrd 06109.5 & Poz-35415 & Peat & $1230 \pm 30$ & $1068-1261$ \\
\hline Lrd 06169.5 & Poz-35433 & Peat & $2350 \pm 30$ & $2331-2461$ \\
\hline Lrd 06229.5 & Poz-35434 & Peat & $2850 \pm 40$ & $2854-3136$ \\
\hline Lrd 06289.5 & Poz-35435 & Peat & $3635 \pm 35$ & $3849-4081$ \\
\hline \multicolumn{5}{|l|}{ Lake Lourdes } \\
\hline Lrd 0726.5 & Poz-27925 & Charcoal & $1120 \pm 30$ & $956-1166$ \\
\hline Lrd 0780.5 & Poz-27924 & Charcoal & $1670 \pm 50$ & $1417-1702$ \\
\hline Lrd 07149.5 & Poz-27923 & Charcoal & $2250 \pm 35$ & $2154-2343$ \\
\hline Lrd 07217.5 & Poz-27949 & Charcoal & $2940 \pm 90$ & $2872-3341$ \\
\hline Lrd 07300 & Poz-27951 & Charcoal & $4410 \pm 100$ & $4882-5311$ \\
\hline Lrd 07368 & Poz-27947 & Charcoal & $3950 \pm 50$ & $4245-4524$ \\
\hline Lrd 07430.5 & Poz-27950 & Charcoal & $4640 \pm 60$ & $5071-5581$ \\
\hline Lrd 07504.5 & Poz-27948 & Charcoal & $5880 \pm 50$ & $6560-6833$ \\
\hline Lrd 07562.5 & Poz-27945 & Charcoal & $6480 \pm 70$ & $7266-7508$ \\
\hline Lrd 07635.5 & Poz-27952 & Charcoal & $7660 \pm 80$ & $8340-8599$ \\
\hline Lrd 07707.5 & Poz-27943 & Charcoal & $9060 \pm 100$ & $9905-10502$ \\
\hline Lrd 07779.5 & Poz-27944 & Charcoal & $11330 \pm 80$ & $13071-13353$ \\
\hline
\end{tabular}

correlations were then calculated for each core between CHArcoal Concentration $\left(\mathrm{mm}^{2} \mathrm{~cm}^{-3}\right)$ and deposition time. Then, betweensites CHAR variability was displayed with boxplots (Fig. 3). In addition, we compared median distribution using a non-parametric two-sample Mann \& Whitney test (Fig. 3) Chronological splitting of datasets was made according to the common chronological parts of the records.

\subsection{Inferred fire frequency (IFF)}

The whole IFF calculation was performed under the $\mathrm{R}$ open source statistical environment (R Development Core Team, 2009). This method (Higuera et al., 2010) consisted of: 1) CHAR records were resampled to equal-time intervals (as in Long et al., 1998) using a window defined on the record with the coarsest time resolution, that is Ech peat bog $\left(25 \mathrm{yrs} . \mathrm{cm}^{-1}\right) 2$ ) log-transformation of the data (LogChar) to reduce variance, 3 ) Background CHARcoal (BCHAR) was estimated with a Loess filter (250 yrs moving window) allowing calculation of the peak component (LogcharBchar), 4) threshold-value (Tv) within the range of values with the lowest sensitivity to the number of peaks detected, was derived by plotting a frequency distribution histogram of peak component against a cumulative curve of peaks number. All peaks above this Tv were considered as single fire episodes and, 5) smooth fire episodes frequencies (500yrs moving window, K1D software, Gavin et al., 2006).

\subsection{Between sites variability in fire frequency and composite record}

We compared median Fire Return Interval (FRI, Fig. 4) using a non-parametric two-sample Mann \& Whitney test (Long et al., 2007; Ali et al., 2009). As we wanted to build-up a composite curve of IFF averaging the four sites, we normalized the series following the three steps procedure decribed by Power et al. (2008), i.e. minimax rescaling, box-cox transform and $Z$-score calculation. These three steps were apllied on Inferred Fire Frequency (no. Fires/ 500 years, 25 years resolution). We then averaged the normalized values so that each curve contributes equally (Gavin et al., 2006). The 95\% confidence interval was based on the standard deviation of the four sites' $Z$-scores (Fig. 6) so that it reflects between sites variability.

\section{Results}

\subsection{Lithology}

Lithology of the records did not feature major lithological change during the Holocene. Analyzed sections of the cores consist 
of brown fibrous peat for Lourdes peat bog and Biscaye peat bog, brown organic gyttja for Lake Lourdes, lacustrine organic silts and $(370-330 \mathrm{~cm})$ and brown fibrous peat $(330-10 \mathrm{~cm})$ for Ech peat bog. The absence of detrital input is underlined by very low variations in gamma density measurements (Fig. 2). Only the age-depth models introduce variability in sedimentation dynamics with a general Holocene trend toward an increase in sedimentary accumulation rate i.e. a decrease in deposition time for Lake Lourdes, Ech and Biscaye peat bogs.

\subsection{Charcoal accumulation rate, basin type and size}

The first important feature is the absence of significant correlation between charcoal concentration and sedimentation rate (in yrs $\mathrm{cm}^{-2}$ ) except for Lake Lourdes (Fig. 2). Pearson's correlation coefficients are $0.06,0.71,0.22$ and 0.11 for Lourdes peat bog, Lake Lourdes, Biscaye peat bog and Ech peat bog records respectively. This indicates that sedimentary processes may have little influence on charcoal accumulation in raised peat bogs compared to lakes. Therefore, there is no significant differences between charcoal concentration and charcoal accumulation rate, except at the bottom section of Lake Lourdes and Ech peat bog, and at the top section of Biscaye peat bog where deposition time is significantly higher.

Second, CHAR values differ across the sites (Fig. 3): at Lourdes peat bog it was between 0 and 8.8 (mean $=0.36)$, at Lake Lourdes it was 0-3.4 (mean $=0.52$ ), at Biscaye peat bog CHAR ranged from 0 to 4.2 (mean $=0.26$ ) and at Ech peat bog it was 0-8.3 (mean $=0.29$ ).

There is no discernable relationship between charcoal accumulation rate and basin size either, given the respective size of each site (Table 1). Globally, means and medians are comparable (Fig. 3) between peat sites whereas Lake Lourdes emphasizes different distribution features. Taking into account common chronological periods between sites, Lake Lourdes systematically displays $p$-values $<0.05$ (Mann \& Whitney test) when comparing its distribution with the three peat bogs, (except with Ech peat bog during the 6750-4000 cal a BP window), which means that its distribution is significantly dissimilar. Means and medians of CHAR in the peat bogs are lower than in the lake, but their distributions are more stretched towards extreme values: for instance Ech and Lourdes peat bogs between 4000 and $1000 \mathrm{cal}$. BP have their third and fourth quantiles significantly larger. To summarize these results, CHAR distribution is similar between peat bogs but dissimilar between peat bogs and lake. CHAR values are more homogenous in Lake Lourdes as they are equally centered on the mean (Fig. 3). All those contrasting parameters suggest differential charcoal accumulation between bogs and lake.

CHAR trends can be chronologically described as follows (Fig. 3): 1) the early Holocene (11700-8500 cal a BP) is characterized by a high steady background with numerous minor peaks (in Lake Lourdes and
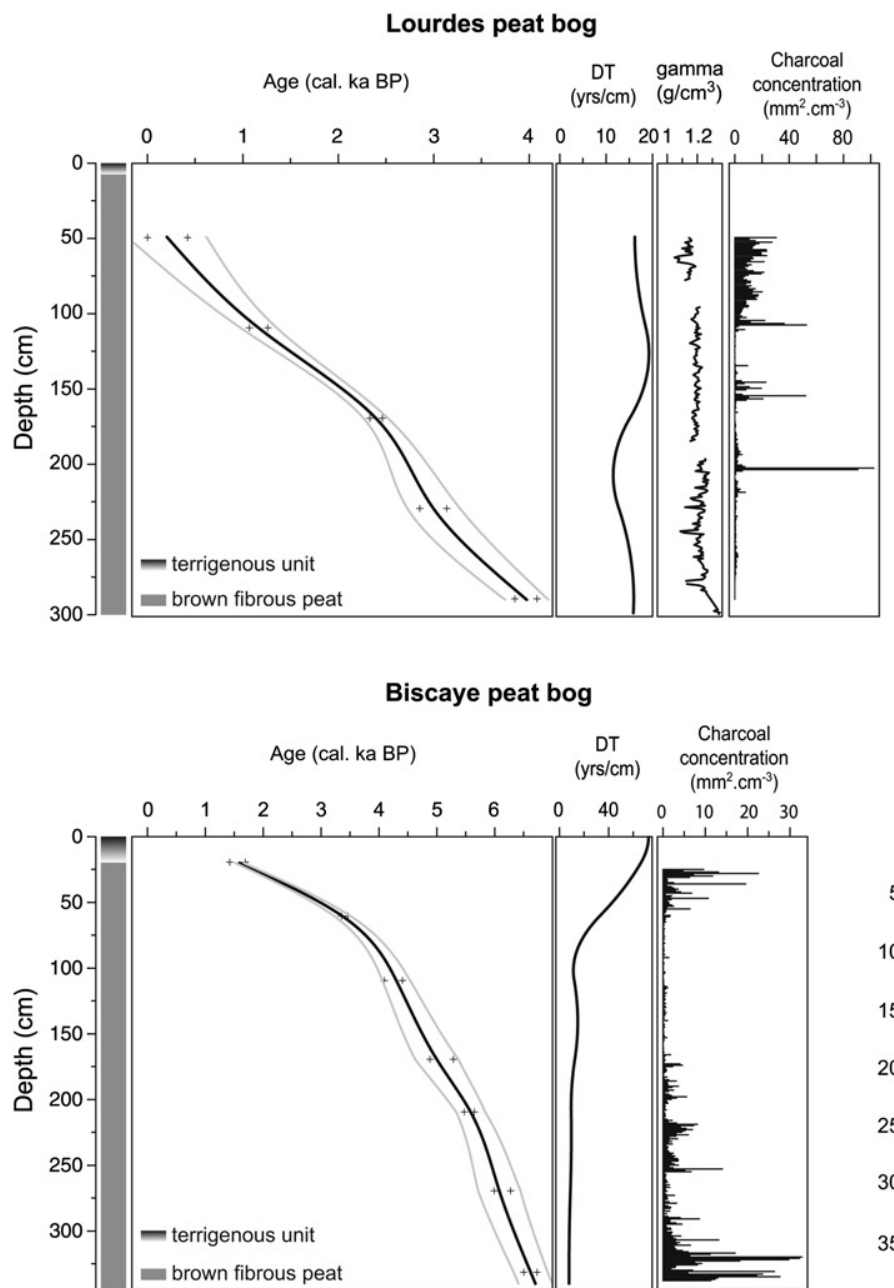

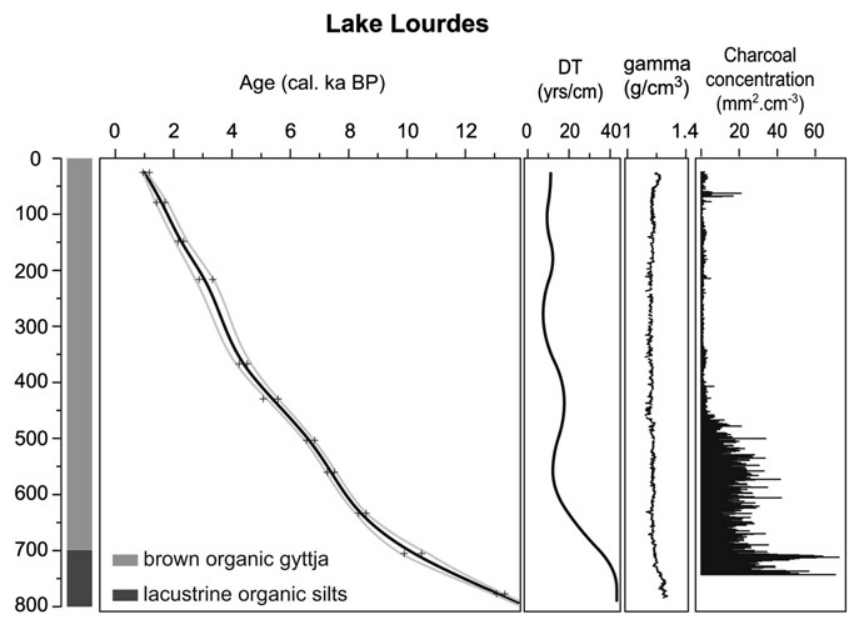

Ech peat bog

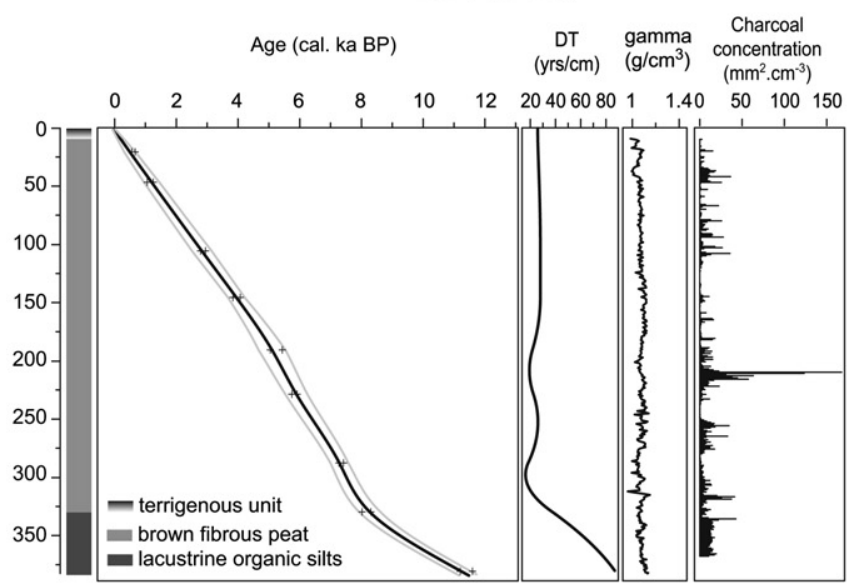

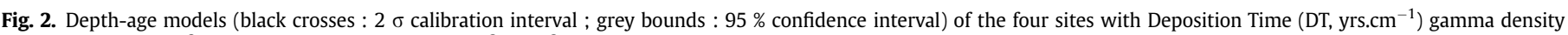
measurements $\left(\mathrm{g} / \mathrm{cm}^{3}\right)$ and charcoal concentration $\left(\mathrm{cm}^{2} \mathrm{~mm}^{-2}\right)$. Gamma density measurements are not available for Biscaye peat bog. 


\section{Lourdes peat bog Lake Lourdes Biscaye peat bog Ech peat bog}

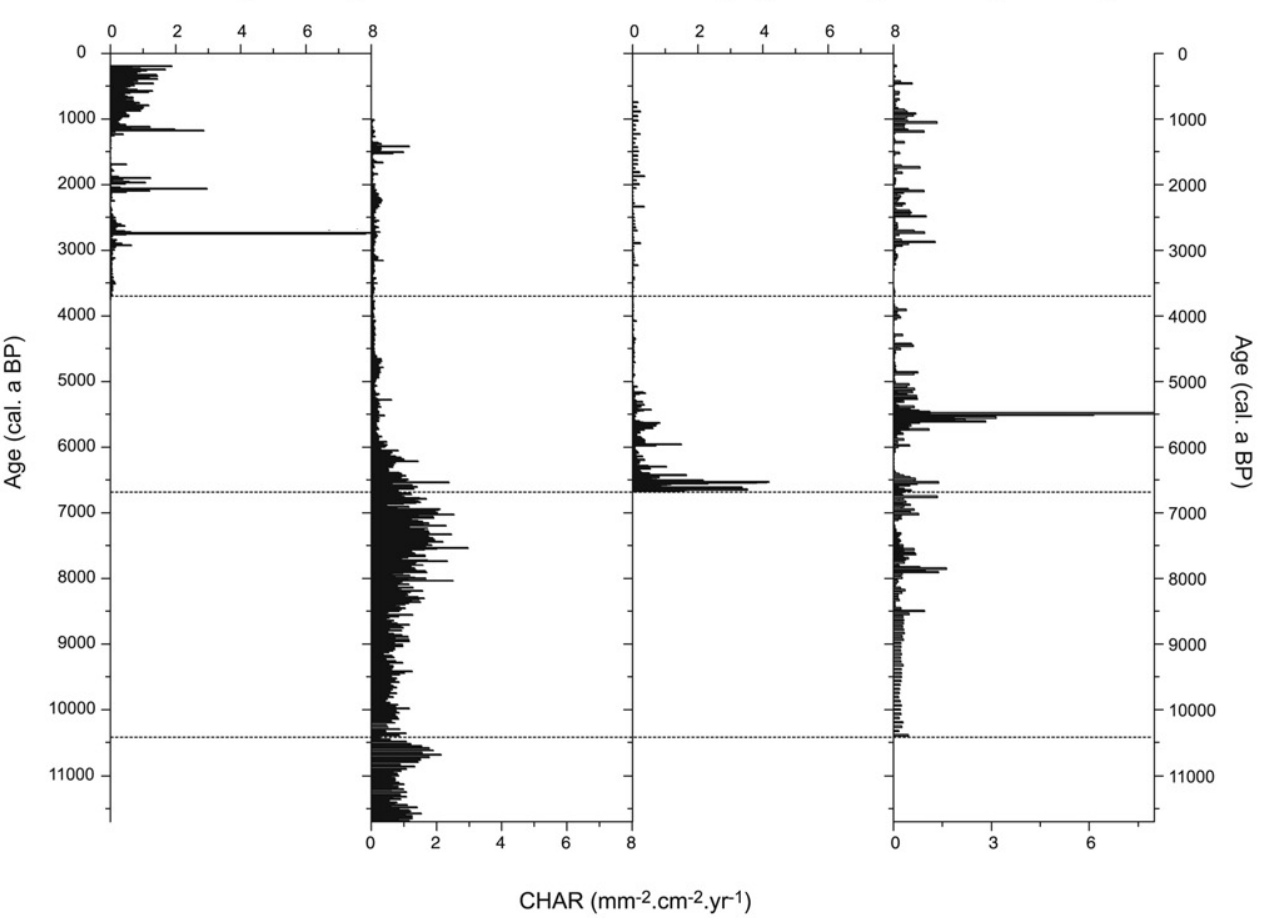

b Boxplot of CHAR for common chronological periods

$10500-6750$

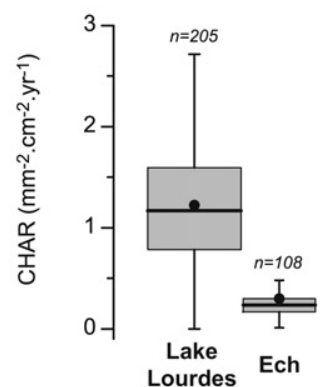

$p$ value

$2.2 * 10^{-6}$

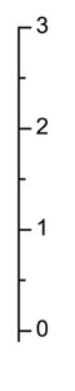

$\begin{aligned} \text { Lake Lourdes } & \\ \text { Biscaye } & 2.6^{\star} 10^{-6} \\ \text { Ech } & 0.0751\end{aligned}$
$6750-4000$

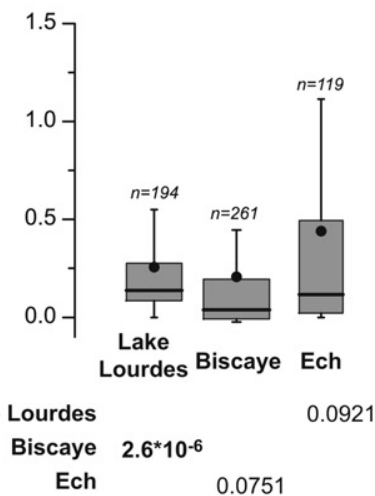

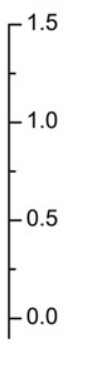

Lourdes

$4000-1000$

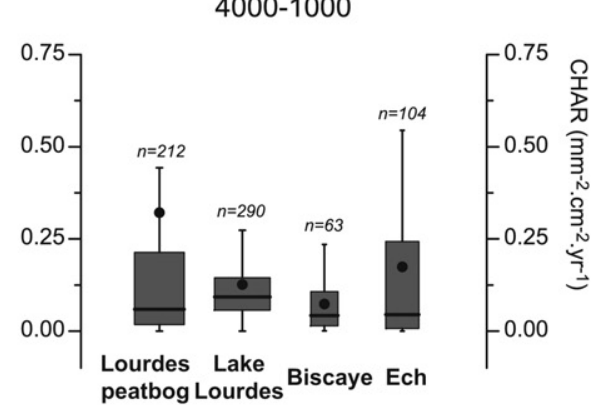

0.004350 .05870 .1992

$1.31^{\star} 10^{-6}$

0.00140 .5468

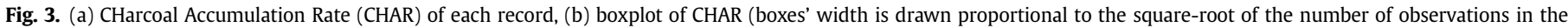

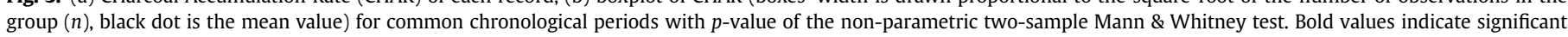
dissimilar distribution $(p<0.05)$.

Ech peat bog records) and punctual increase of CHAR at ca 11700-11500 and 10700-10250 in Lourdes Lake record; 2) the midHolocene (8500-4000 cal. BP) features an abrupt change in CHAR with an increase of background and higher peaks. The maximum is reached at ca 7500 cal a BP in Lake Lourdes and then CHAR decreases until ca $6500 \mathrm{cal}$ a BP where a minimum is reached in Lake Lourdes, Biscaye and Ech peat bogs records. CHAR pattern during this period is more complex in Ech peat bog record with another minimum between ca 7500 and $7200 \mathrm{cal}$ a BP. After $6500 \mathrm{cal}$ a BP, CHAR values emphasizes a flat trend until ca 6000 cal a BP (Biscaye and Ech peat bogs) and even a short-time decrease in Lake Lourdes record between
6400 and 6250 cal a BP. Higher CHAR values are noted between 6000 and $5250 \mathrm{cal}$ a BP for Biscaye and Ech peat bogs in particular and then isolated events in Ech peat bog and Lake Lourdes with low background until $4000 \mathrm{cal}$ a BP; 3 ) the late Holocene (4000-1000 cal a BP) globally displays very low background except in Lourdes peat bog. In the four sites CHAR values reach their minimum until $3000 \mathrm{cal}$ a BP. From this point there are regular isolated peaks from high amplitude (Lourdes peat bog) to medium (Ech peat bog) and low amplitude (Lake Lourdes, Biscaye peat bog). Based on the four sites, charcoal accumulation appears generally lower during the late Holocene than during the mid-Holocene. 
Lourdes peat bog
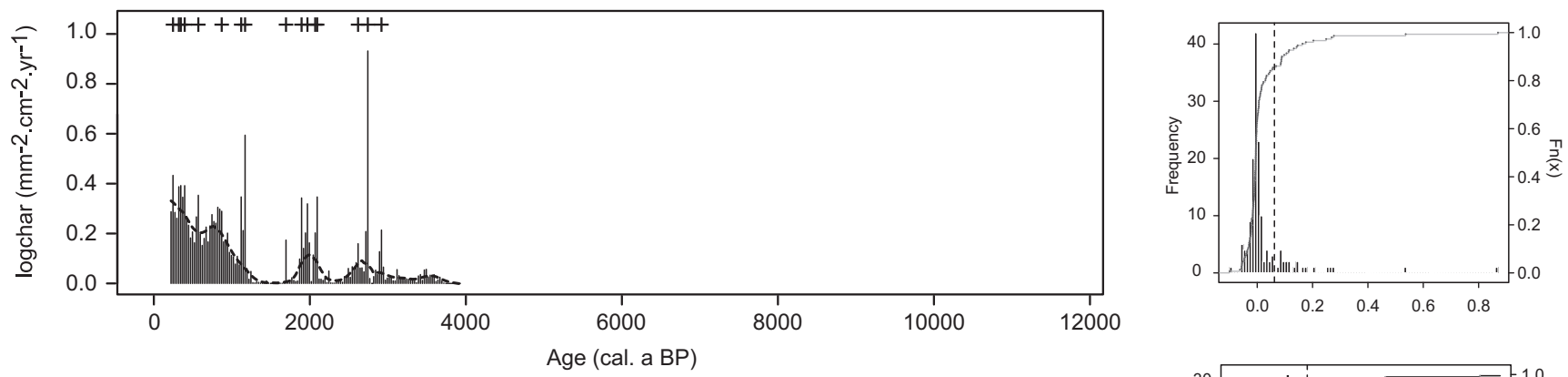

Lake Lourdes
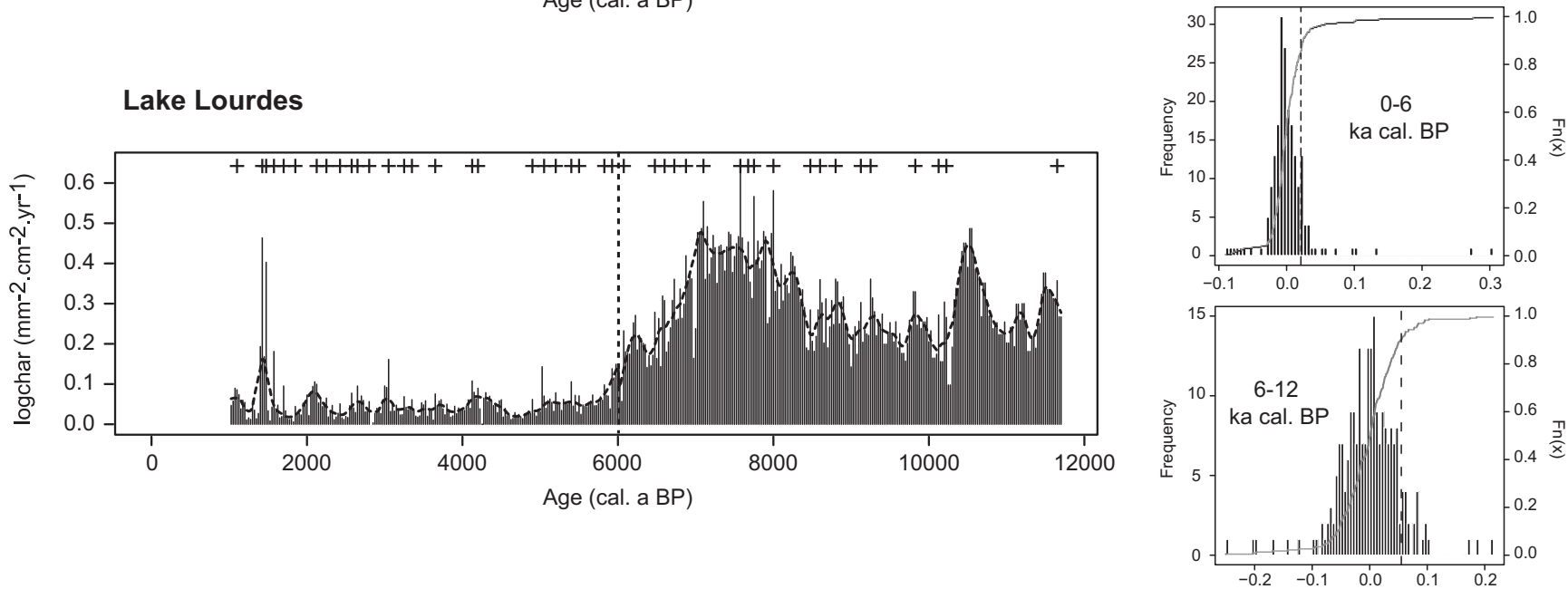

Biscaye peat bog
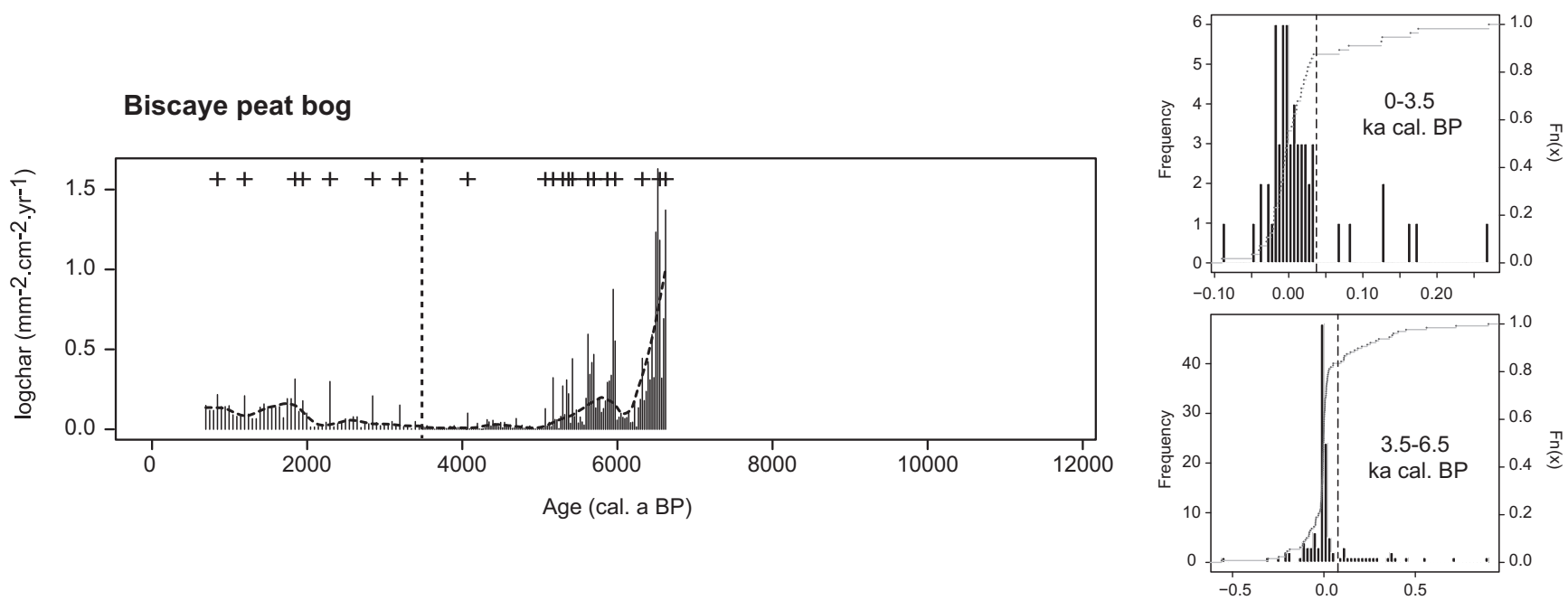

Ech peat bog
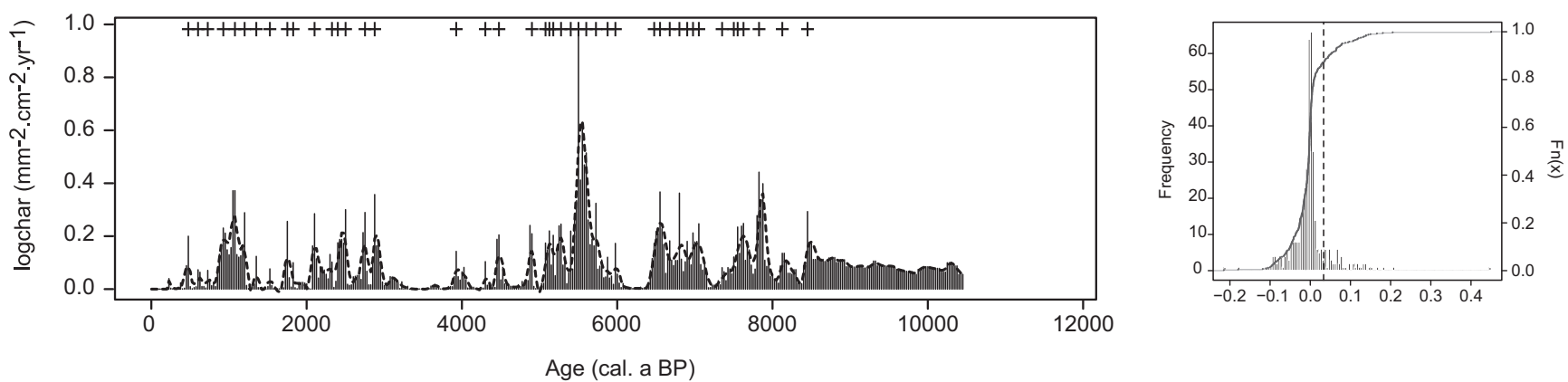

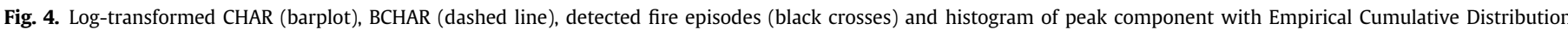
Function ECDF, (dotted line) for threshold-value selection (dashed line). 


\subsection{Signal decomposition and composite frequency}

Fig. 4 displays the decomposition method for fire events detection on the four sites. Two records were split into two datasets for charcoal signal decomposition. The variance of CHAR in Lake Lourdes was too high even after log-transformation (Long et al., 1998) and then threshold-value needed to be locally defined, but the two parts were resampled with the same time window. Biscaye peat bog was also split into two datasets because of the variability in deposition time whose average was two times higher after ca 3500 cal a BP (Fig. 2). Then, the resampling window was doubled for the 3500-500 cal a BP part.

Fire episodes detected for each site are distributed as follows: sixteen in ca 2500 yrs for Lourdes peat bog (Mean Fire Interval, $\mathrm{MFI}=178 \mathrm{yrs}$ ), forty-four in $11700 \mathrm{yrs}$ for Lake Lourdes (MFI $=245 \mathrm{yrs}$ ), twenty in $6000 \mathrm{yrs}$ for Biscaye peat bog (MFI = 303yrs) and forty-four in $10500 \mathrm{yrs}$ in Ech peat bog (MFI = 230yrs). Taking into account common chronological periods rather than the whole record, FRIs shows relative consistency between the sites throughout the Holocene, except for Biscaye peat bog during the late Holocene (Fig. 5). This discrepancy is also highlighted by the fact that the variability of IFF at Biscaye peat bog (Fig. 5) does not display the same range as that of the three other sites.

Synchronicity between sites can be assessed from the composite curve (Fig. 6). The mean (bold curve) is an estimate of fire frequency within the study area as it reflects fire frequency across the four sites (Fig. 6). There is a millennial variability with relatively high fire frequency between 8000 and 5000 cal a BP, low fire frequency between 5000 and $3000 \mathrm{cal}$ a BP and high fire frequency between 3000 and 500 cal a BP. Within this frame, centennial variability is depicted by shorter increase/decrease. Indeed, seven phases of high fire frequency (ie $Z$-scores $>0$ ) occurs between ca 7900-7400, $7100-6400,6100-4900,3000-2500,2400-1600$ and $800-500 \mathrm{cal}$ a BP punctuated by low fire frequency phases (Z-scores $\leq 0$ ) at ca $8200,7200,6200,4900-3000,2450,1500$ and 750 cal a BP. Confidence intervals (grey bounds) were calculated to reflect the variability between sites. This local variability has two main features: 1) the range of confidence intervals is narrower between 8500-3500 (mean confidence interval range $=1.7$ ) than afterward (mean confidence interval range $=2.3$ ), that is to say the late Holocene exhibits stronger spatio-temporal variability in fire activity and 2) there are eight phases where the records are highly synchronous: at ca 500, 1000, 2200, 3800, 4900, 6700 and 7600 cal a BP.

\subsection{Vegetation history}

Table 3 summarizes the major vegetation changes along with the major phases of human impact extracted from the previously published Lourdes basin pollen data (Mardones and Jalut, 1983; Reille and Andrieu, 1995). Briefly, the main results from this previous studies show that the onset of the Holocene was marked by the rapid expansion of broad-leaved forest with Quercus at ca 11700 and Corylus at ca 10500 cal a BP. Corylus then dominated the local vegetation throughout the early Holocene and collapsed between ca 8600 and ca 6800 cal a BP. Between ca 8000 and 5000 cal a BP, there are high amplitude variations $(20-30 \%)$ in arboreal pollen percentages (except in Lourdes peat bog) without evidence for strong human activities even if there are isolated occurrences of Cerealia-type pollen between ca 7300 and $6000 \mathrm{cal}$ a BP (Reille and Andrieu, 1995 and Fig. 6). The first phase of regular but temporary agriculture is recorded between 6000 and $5000 \mathrm{cal}$ a BP. The two major botanical events of the mid-Holocene were the expansion of Alnus (between 6800 and 5500 cal a BP) and Fagus (ca $4000 \mathrm{cal}$ a BP). The late Holocene was then characterized by the dominance of Fagus, increasing signs of agricultural activities becoming permanent, especially from ca 3000 cal a BP, and a subsequent general reduction of arboreal pollen percentages from ca $2200-1500$ cal a BP in particular (Reille and Andrieu, 1995 and Fig. 6).

\section{Discussion}

\subsection{Impact of basin type, size and sedimentary patterns on charcoal} accumulation rate and fire frequency reconstruction

Our results show a general consistency in the derived fire histories, but there are discrepancies at the centennial scale that needs to be discussed in terms of synchrony/asynchrony with respect to site type and chronology. Fire frequencies are most synchronous across the analyzed sites in the Lourdes basin before 3000 cal a BP (Fig. 5). However, asynchrony after 3000 cal a BP between Lourdes peat bog and Lake Lourdes which are the closest sites from each other, is evident. Lourdes peat bog is located immediately next to the shore of Lake Lourdes but their coring points are located $1 \mathrm{~km}$ away from each other (Fig. 1, Table 1). Therefore, fire episodes recorded in Lourdes peat bog should also be recorded in Lake Lourdes unless we assume a source area $<1 \mathrm{~km}$. Even if Lourdes peat bog experienced peatland fires, charcoal from those fires should have accumulated in the western part of the lake and then to its deepest zone where the coring was performed (Whitlock and Millspaugh, 1996; Whitlock and Larsen, 2001). Lourdes peat bog dates were established by sampling bulk sediments after removing rootlets while dates from Lake Lourdes were based on sampled charcoal pieces (Table 2). It is impossible for us to evaluate the inbuilt age of those dated charcoal pieces but it is well known that this type of material can produce older ages (Gavin, 2001; Kennet, 2002; Oswald et al., 2005) by ranges of several decades to several centuries. Last, the two sites emphasize strongly similar IFF pattern between 3000 and 1000 cal a BP with a 300-400 yrs lag and highly similar FRI distribution (Fig. 5). Thus, it is unlikely to assume contrasting patterns of fire history between the two sites, and most probably the discrepancy can be explained by chronological control.

The second contrasting patterns in the Lourdes basin fire history seems to be linked with site type. Indeed, charcoal accumulation differs in Lake Lourdes compared to bogs. Bog sites (Lourdes, Biscaye and Ech) have variable areas (Table 1) but shows remarkable consistency in CHAR distribution (Fig. 3) suggesting that bogs have the same charcoal accumulation characteristics: low BCHAR, distribution stretched towards extreme values and well-isolated peaks. The CHAR distribution of Lake Lourdes systematically emphasizes strong dissimilarities with bog sites at all given chronological periods. This line of evidence of basin type influence on charcoal accumulation rate may be explained by the absence of reworking processes within peat bogs (Clark and Patterson, 1997) which seems to produce a less noisy signal, with less BCHAR compared to lakes (Fig. 5), even if the variability of BCHAR remains high, probably because of extra-local transport (Clark and Royall, 1996) and/or variability in fire size (more precisely, variation of the Potential Charcoal Source Area to fire-size ratio, see Higuera et al., 2007). This could explain the main feature of Lake Lourdes CHAR, that is higher values in the first half of the Holocene, lower in the second half. Even if there is no indication in gamma density measurements of major lithological change, this abrupt shift in CHAR at ca 6500 cal a BP can partly be explained by the deposition time change from this point (from 20 to $10 \mathrm{yrs} / \mathrm{cm}$, Fig. 2). Indeed Lake Lourdes is the only site where deposition time and charcoal concentration are significantly correlated. A higher deposition time might smooth the signal and increase the background. 


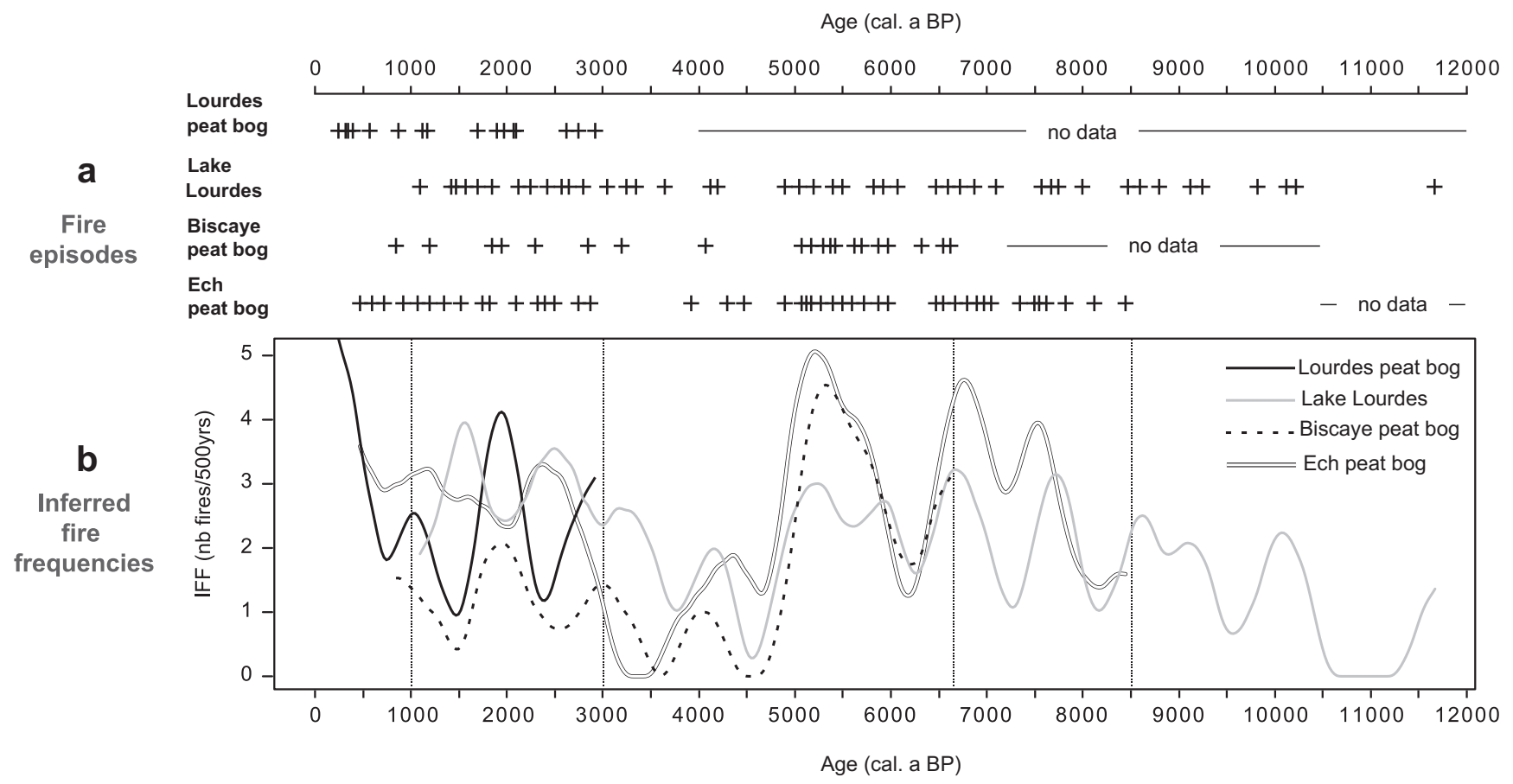

$8500-6750$

$6750-3000$

$3000-1000$
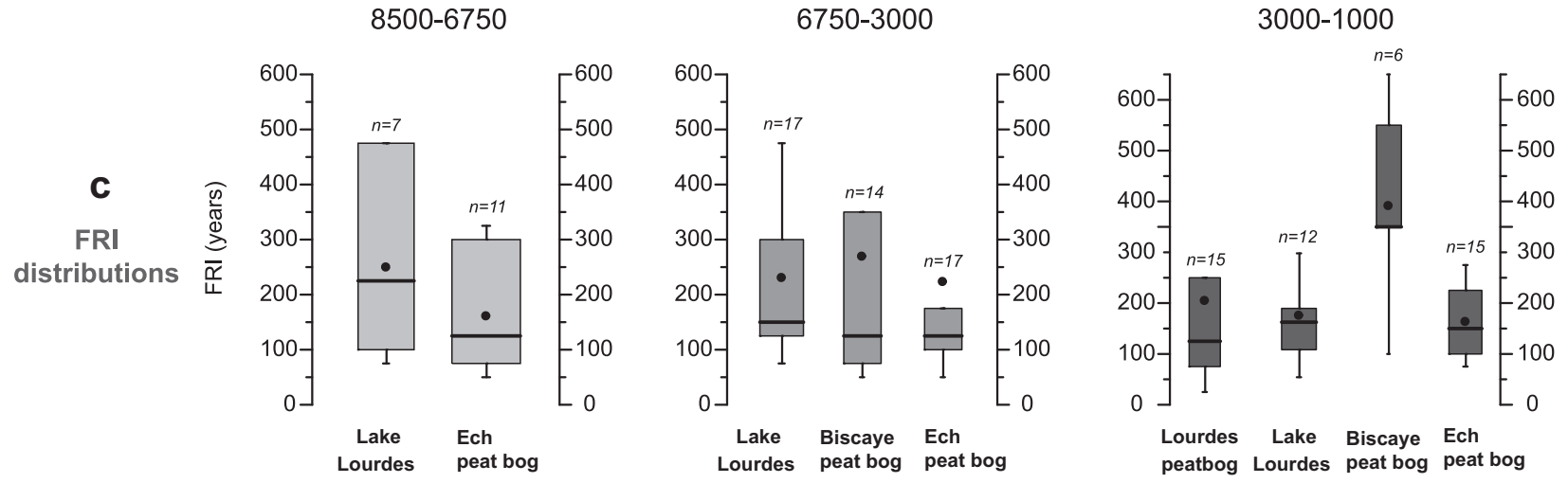

$\begin{array}{lll}p \text { value } & 0.2541 \quad \begin{array}{l}\text { Lake Lourdes } \\ \text { Biscaye peat bog } \\ \text { Ech peat bog }\end{array}\end{array}$

0.54980 .2823 Lourdes peatbog

Lake Lourdes

0.8888

Biscaye peat bog

$0.6772 \quad 0.01910 .5457$

Ech peat bog

0.0143

$1 \quad \mathbf{0 . 0 1 2 2}$

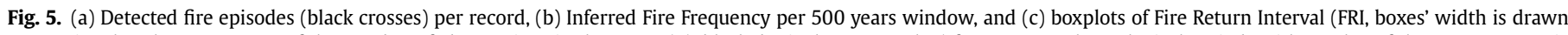

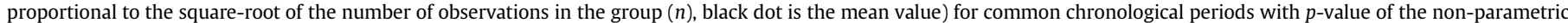
two-sample Mann \& Whitney test. Bold values indicate significant dissimilar distribution $(p<0.05)$.

Another line of explanation could be changing fire size (within the potential charcoal source area) under changing fire regime control. Indeed, fire occurrence in the area seems to be mainly naturally-induced until $6000 \mathrm{cal}$ a BP, while later fire occurrences seem more dependent on the first important phase of agricultural activities. In this landscape it appears that anthropogenic fires might produce more charcoal but are less powerful, less severe (Eckmeier et al., 2007; Fearnside et al., 2001) and above all are controlled and probably results in a smaller area burned. Besides, as the lake is perched, its watershed is very small (so that in case of wildfire, it may burn entirely, which may not be the case for anthropogenically-induced burn with agro-pastoral purposes). It is noteworthy that in Ech peat bog and Biscaye peat bog charcoal peak amplitude is also higher during the first half of the Holocene than after (Figs. 3 and 4). Thus, quicker sedimentary accumulation rate and above all changing fire regime may account for this shift in
CHAR. Such mid-holocene shift in charcoal acumulation rate has already been observed in northeast Italy under increasing anthropogenic control (Kaltenrieder et al., 2010).

Likely, the CHAR distribution of Biscaye peat bog differs between 3000 and 1000 cal a BP interval (Fig. 3). The deposition time of the sediments at Biscaye peat bog (Fig. 2) increases substantially after $3500 \mathrm{cal} \mathrm{a} \mathrm{BP}$ such that the subsamples approach $50 \mathrm{yrs} \mathrm{cm}^{-1}$. In this case, individual fire episodes may not be detected (Higuera et al., 2007). This low CHAR can also be explained by the fact that Biscaye peat bog is located in the bottom of a small wet valley of glacial origin whereas the other sites are perched (Lourdes peat bog) and/or under a dry south-facing slope (Ech peat bog). This type of location may be less favorable to human activities. Actually, Biscaye peat bog has earlier signs of agriculture (Table 3 ) than Lourdes peat bog but they are weaker towards the top of the record corresponding to the last 3500 years (data in Reille and Andrieu, 


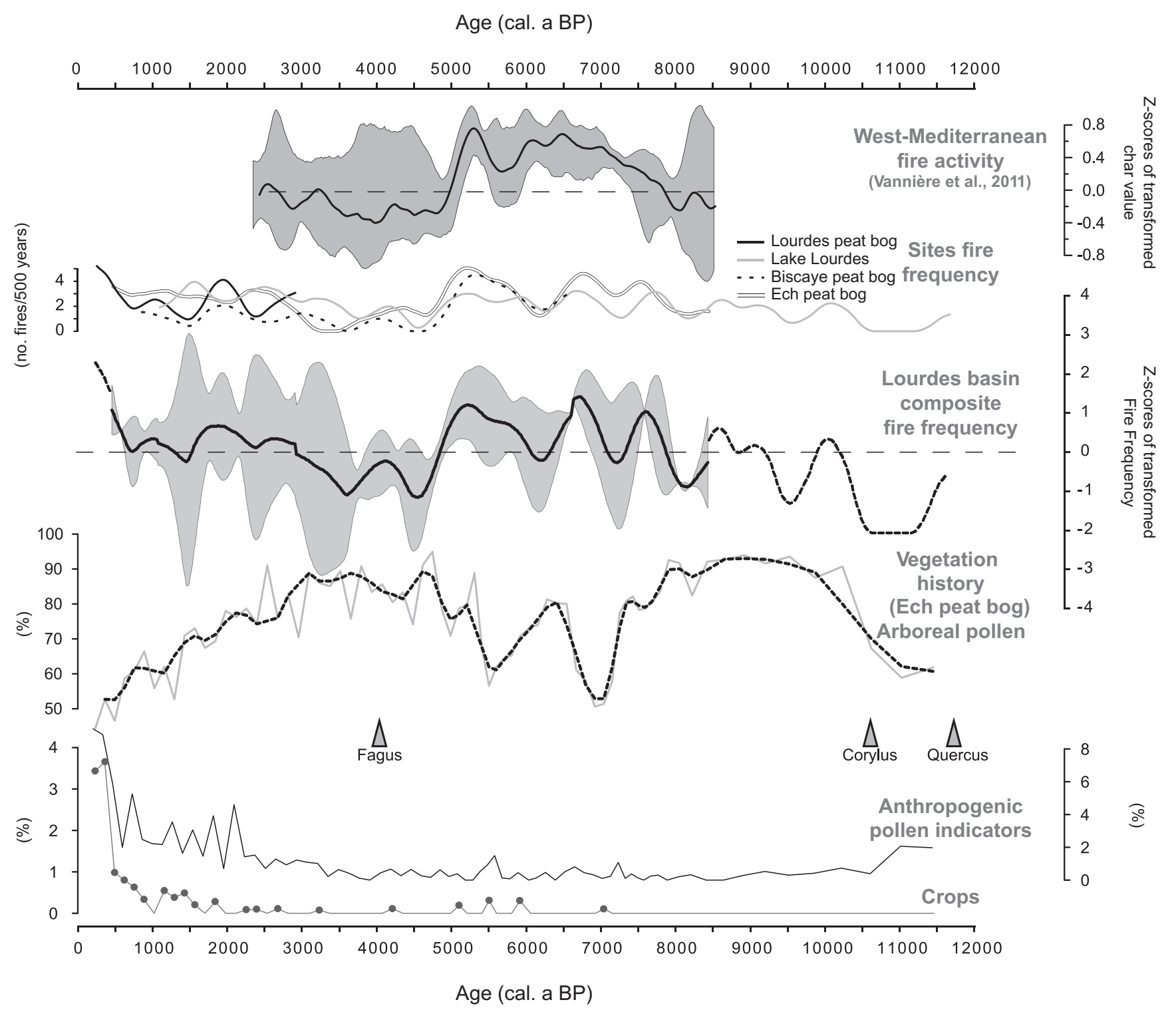

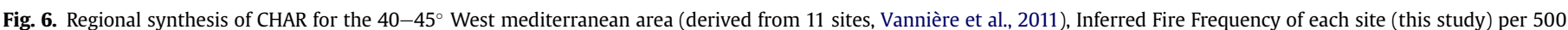

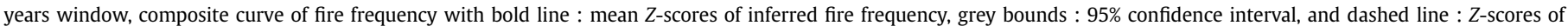

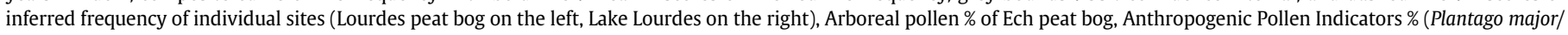

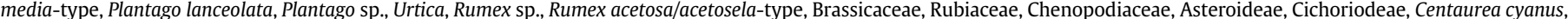

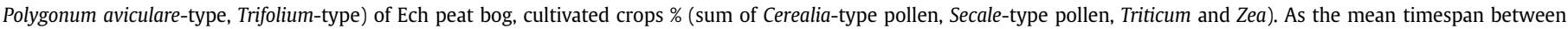

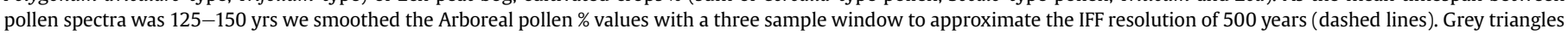
correspond to the expansion of the main arboreal taxa.

1995). This may indicate differential human impact in the Lourdes basin, a phenomenon already described in wider areas of the northeastern Pyrenees (Galop and Jalut, 1994).

The decomposition method for Inferred Fire Frequency calculation (Fig. 4) enables to partly overcome those differences linked to (1) differential BCHAR (Higuera et al., 2007) values linked to site types, (2) location and site size, and (3) sedimentary patterns and deposition time in particular. However, this was made possible because of (1) the selection of study sites with accurate chronological resolution, (2) resampling of CHAR to the same constant time interval (Ali et al., 2009). Therefore, frequency calculation provides a tool to compare Holocene fire histories between sites at both millennial and centennial scales, and then to infer regional patterns (synchrony) versus local variability (asynchrony).

\subsection{Site variability vs. regional fire history}

The early Holocene (11700-8500 cal a BP) is covered by the Lake Lourdes record and shows an increase of fire frequency at $10500 \mathrm{cal}$ a BP. The transition from the Lateglacial to the Holocene is characterized by rapid vegetation changes driven by favorable climatic conditions. In the Pyrenees, the rapid settlement of Quercus, at ca $11700 \mathrm{cal}$ a BP, and then Corylus (hazel), at ca 10500 cal BP probably resulted from the persistence of a dry climate promoting these species against other deciduous trees (Jalut et al., 1992; Reille and Andrieu, 1995). The delayed expansion of hazel was also observed in the southern Alps with a longer lag (2000 yrs) and was triggered by marked summer drought and frequent fires (Finsinger et al., 2006). This high fire frequency (Fig. 6) is probably linked with the dry climatic conditions and greatly benefited from the early Holocene biomass increase. 
Table 3

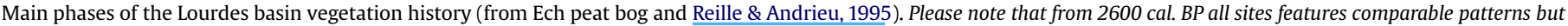
only the chronology of Ech peat bog is sure enough to be described.

\begin{tabular}{|c|c|c|c|c|}
\hline LPAZs/RAPZs & Dates (cal. BP) & Vegetation dynamics & Inferred vegetation change & Inferred human impact \\
\hline Ech 1, RPAZs 10, 11 & $11700-10700$ & $\begin{array}{l}\text { Abrupt } \nearrow \text { Quercus, } \searrow \text { or }=\text { Pinus, } \searrow \\
\text { Poaceae and artemisia }\end{array}$ & $\begin{array}{l}\text { Abrupt change from a rather } \\
\text { open environment to a } \\
\text { closed one }\end{array}$ & None \\
\hline $\begin{array}{l}\text { Ech 2, RPAZs } 12,13 \text {, } \\
\quad 14,15\end{array}$ & $10700-7300$ & $\begin{array}{l}\text { Abrupt } \nearrow \text { Corylus then }=\text {, slight } \searrow \\
\text { Quercus then }=, \searrow \text { Poaceae }\end{array}$ & $\begin{array}{l}\text { Mixed deciduous, Corylus } \\
\text { dominance }\end{array}$ & None \\
\hline Ech 3, RPAZs 16,17 & $7300-5500$ & $\begin{array}{l}\text { Abrupt } \searrow \text { Corylus },=\text { Quercus, slight to } \\
\text { abrupt } \nearrow \text { Betula (not in Biscaye) } \nearrow \text { Poaceae } \\
\text { (not in Biscaye), regular presence of Calluna } \\
\text { and grassland taxa }\end{array}$ & Opening vegetation & $\begin{array}{l}\text { First occurrences of Cerealia- type } \\
\text { pollen (Ech peat bog, Biscaye), signs } \\
\text { of pastoral use especially in Ech peat } \\
\text { bog. First important agricultural phase } \\
\text { (middle Neolithic) }\end{array}$ \\
\hline Ech 4, RPAZ 18 & $5500-4200$ & $\begin{array}{l}\nearrow \text { Alnus, } \nearrow \searrow \text { Quercus,Corylus (in all sites) } \\
\text { and Betula (Ech peat bog),regular occurrences } \\
\text { of Abies and Fagus , sparse occurrences } \\
\text { of Cerealia -type pollen (Ech peat bog, } \\
\text { Le Monge) }\end{array}$ & $\begin{array}{l}\text { Progressive settlement of } \\
\text { moist and shade-demanding } \\
\text { species, denser } \\
\text { forests }\end{array}$ & $\begin{array}{l}\text { End of the previous agricultural phase, } \\
\text { signs of weak pastoral use, with impact } \\
\text { on secondary taxa (e.g. Betula) in Ech peat } \\
\text { bog record }\end{array}$ \\
\hline Ech 5, RPAZs 19, 20 & $4200-2600$ & $\begin{array}{l}\text { Abrupt } \nearrow \text { Fagus, } \nearrow \searrow \text { Corylus and Alnus, } \\
\searrow \text { Betula (Ech peat bog), first occurrence } \\
\text { of Cerealia -type pollen (Lourdes peat bog) }\end{array}$ & $\begin{array}{l}\text { Abrupt rise of Fagus, stability in } \\
\text { forest cover until ca } 3000 \text { cal. BP, } \\
\text { then forest clearances }\end{array}$ & $\begin{array}{l}\text { No signs of agro-pastoral activities } \\
\text { until } \mathrm{ca} 3000 \mathrm{cal} \text {. BP, then signs of } \\
\text { agriculture at all sites }\end{array}$ \\
\hline Ech 6a, RPAZs 21,22 & $2600-1500$ & $\begin{array}{l}\text { Slight } \searrow \text { all arboreal taxa, regular occurrences } \\
\text { of Cerealia -type pollen and Plantago lanceolata }\end{array}$ & $\begin{array}{l}\text { Fagus dominance in a context of } \\
\text { forest opening }\end{array}$ & $\begin{array}{l}\text { Regular agricultural activities, increasing } \\
\text { grazing pressure, repeated clearances }\end{array}$ \\
\hline Ech 6b, RPAZs 22,23 & $1500-200$ & $\begin{array}{l}\searrow \text { all arborean taxa, appearance of } \\
\text { Castanea and Juglans general } \nearrow \text { grassland } \\
\text { taxa } \searrow \text { all arboreal taxa, regular occurrences } \\
\text { of Cerealia -type pollen and Plantago lanceolata } \\
\text { appearance of Secale }\end{array}$ & $\begin{array}{l}\text { Acceleration of previously } \\
\text { observed trends: forest opening, } \\
\text { strong development of herbaceous } \\
\text { vegetation }\end{array}$ & $\begin{array}{l}\text { Agro-pastoral pressure increases to } \\
\text { reach a maximum ca } 400 \mathrm{cal} \text {. BP }\end{array}$ \\
\hline
\end{tabular}

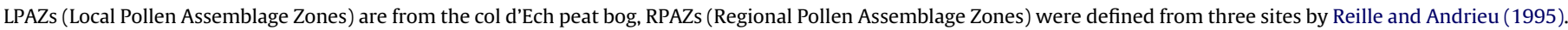
$\nearrow=$ increase

$\searrow=$ decrease.

$=$ means steadiness.

From 8500 cal a BP onwards, at least two sites contribute to the composite fire frequency and comparison with the regional Mediterranean synthesis of fire activity (CHAR synthesis) is also available (Fig. 6, Vannière et al., 2011). The mid-Holocene (8500-5000 cal a BP) in the Lourdes basin is a period of contrasted fire frequency with centennial oscillations and a millenial pattern similar to the regional Mediterranean fire activity (Fig. 6). This similarity suggests large-scale control over the fire regime. The second argument supporting this hypothesis is the synchronicity of frequency curves and the similarity between median distribution of FRIs over the 8500-5000 cal a BP interval (Fig. 5, Long et al., 2007; Carcaillet et al., 2009). As the current natural fire season is summer, the driving mechanisms that may explain this period of high fire frequency are higher than today summer $\mathrm{T}^{\circ}$ and a well marked seasonality (summer precipitation decrease) recorded at the regional scale (Peñalba et al., 1997) and at the European scale between 8000 and 5500 cal a BP (Holocene Thermal Maximum (HTM), Calvo et al., 2002; Renssen et al., 2009). Several Holocene studies from the Alps also provide lines of evidence for retreat of glaciers between 8000 and 6000 cal a BP (Hormes et al., 2001; Maish et al., in Tinner and Amman, 2001; Joerin et al., 2008). In the Lourdes basin, the millennial variability, i.e. fire frequency above the Holocene mean from 8000 to $5000 \mathrm{cal}$ a BP is consistent with those paleaoclimatic reconstructions of increased summer drought. Consequently, it is also tempting to see the effect of moister oscillations within the HTM in the centennial variability of fire frequency: decreases at ca 8200 and $6200 \mathrm{cal}$ a BP are synchronous with the cold and moist oscillation ca 8200 cal a BP (Alley et al., 1997) and recorded glacier advance ca 6200-6000 cal a BP in the Alps (Nicolussi et al., 2009) and in the Pyrenees (Gellatly et al., 1992; Pallas et al., 2006).

However, relatively high fire frequency since 7000 cal a BP may also be partially triggered by local factors such as human impact as there are regular occurrences of Ceralia-type pollen in the Lourdes basin (Table 3, Fig. 6). Therefore, climate control can be considered as the major forcing factor over fire occurrence during the mid-
Holocene at the millennial scale but shorter variability may be accounted for by other factors such as human impact and/or firevegetation feedbacks. Indeed, it seems that fire influenced woody vegetation (AP percentages) but that under a given threshold of available biomass, fire may occur less frequently (Fig. 6).

From 5000 to ca 3500 cal a BP fire frequency in the Lourdes basin features an abrupt decrease which is in accordance with the regional Mediterranean fire activity (Vannière et al., 2011). Fire frequency is still rather synchronous between sites as underlined by the similar distribution of Fire Return Interval (Fig. 5) and the narrow confidence interval of the composite frequency (Fig. 6). At this time, Alnus (6800-5500 cal a BP) and then Fagus (4000 cal a BP) colonized the area, and quickly became dominant in pollen spectra (Galop and Jalut, 1994). This vegetation shift might indicate cooler/wetter climatic conditions (increasing precipitation and/or atmospheric humidity, Jalut et al., 1996) which may have affected fuel-moisture levels (Vannière et al., 2011). There are fewer signs of human activities than before (Fig. 6), which suggests that climatic control is dominant in promoting fire occurrence during the midto-late Holocene transition. Societies may have also been affected by these wetter/cooler oscillations from the local (Galop et al., 2007) to European scales (Magny, 2004; Magny et al., 2009). The conjunction of increased moisture, vegetation shift towards taxa with assumed low specific flammability (Ellenberg, 1982 in Clark et al., 1989) and decrease of agro-pastoral activities leads then to weaken fire activity.

Finally, the last 3000 years exhibits an increase in fire frequency which is asynchronous between sites. However FRI distributions do not display the same consistency than before (Fig. 5) and above all the general trend is not in accordance with regional fire activity (Fig. 6). As discussed above, this discrepancy may be partly due to dating issues but it may be also linked to local controls, most likely human impact. Moreover, centennial variability in fire frequency apparently mismatches with the rapid climatic oscillations, such as the Medieval Warm Period (ca 1000-500 cal a BP) or the Little Ice 
Age (ca 600-100 cal a BP), reconstructed in the Pyrenees (Buntgen et al., 2008; Morellon et al., in press), in Galicia (Desprat et al., 2003) and in the Alps (Millet et al., 2009). Therefore, fire frequency in the Lourdes basin is disconnected from the regional pattern in the late Holocene, and the control of fire occurrence seems local. It is most probably agro-pastoral activities as shown by the increase of both Anthropogenic Pollen Indicators (API) and cultivated crops (Fig. 6) at ca $3000 \mathrm{cal}$ a BP which is the point from which fire frequency again exceeds the Holocene baseline $(Z$-scores $>0$ from $3000 \mathrm{cal}$ a BP onwards). Once more, the opposing trends between fire frequency and arboreal pollen percentages (Fig. 6) suggest that human-induced fire plays a prominent role in landscape opening at the Lourdes basin scale. However, fire-vegetation relationships seem to be more complex and less linear than during the midHolocene. Indeed, the long-lasting decrease in AP percentages is stronger than those of the mid-Holocene but under a fire frequency which is lower. Thus agro-pastoral fire may not be the only one driver of forest clearances. Increasing grazing and agricultural pressure may help to maintain spaces open without fire or with less frequent fires (Clark et al., 1989). Besides, the remaining wood may be exploited (Rius et al., 2009) for other activities such as metallurgy which are attested to at the regional level (Galop et al., 2001; Monna et al., 2004; Jouffroy-Bapicot et al., 2007; Pelachs et al., 2009). Nevertheless, this hypothesis has to be considered with caution given the lack of archaeological investigations and evidence for such activities in the area.

\subsection{Implications for reconstructing holocene fire regimes}

Our data do not allow discussion of charcoal source area or particle transport, but they clearly show that macrocharcoal as a local proxy could also reflect local-to-regional scale processes even in single site analysis, as the HTM is reliably recorded in Lake Lourdes, Biscaye and Ech peat bogs for instance. Generally speaking those three records reflects the climatic differences between the mid- and late Holocene. It means that on each site fire regime also reflects regional forcing factors. On the contrary, the predominance of human impact as a control factor over fire occurrence from 3000 cal a BP onwards blurred the climatic-fire-vegetation relationship. While fire history appears coherent at the millennial scale in the Lourdes basin, it would be difficult to generalize the detailed history of human fire-use derived from a single site because of the centennial variability between sites within the millennial common pattern. There are also differences in the range of fire frequency values between Biscaye peat bog and the other sites. As an example, Ech peat bog experienced very regular fires while both Lourdes peat bog and Lake Lourdes show abrupt increase/decrease throughout the period (Figs. 5 and 6). Those discrepancies are probably linked with differential land-use pressure around the coring sites.

Moreover, the switch to an anthropogenic-dominated fire regime seems to be asynchronous at a regional scale: an increasing trend can be observed earlier in the western part of the Pyrenean piedmont (ca $4000 \mathrm{cal}$ a BP; Rius et al., 2009) and in the Andorran Pyrenees (ca 5200 to 3600 cal a BP; Miras et al., 2007), and later eastwards (ca 2500-2000 cal a BP; Vannière et al., 2001; Galop et al., 2002). Those discrepancies might be linked with differential and asynchronous human impact.

Finally, in this bioclimatic context, the results suggest that there is a rather mechanical link between increasing human impact and increasing fire frequency during the late Holocene. However this human-induced increase remains lower than the mid-Holocene fire activity (Fig. 6). Even if human activities directly control the increase of fire frequency during the last 3000 years, it does not attenuate the general picture of a transition from a warmer mid-
Holocene to a colder late Holocene in the northern Pyrenees and at the European scale (Davis and Brewer, 2009; Renssen et al., 2009). These results suggest that even under direct anthropogenic control, fire regime in the area tend to be indirectly modulated by climate and vegetation.

\section{Conclusions}

The four records of fire history and the derived composite fire frequency provide an overview of climate-vegetation-human-fire relationships during the Holocene. The results show:

1) a clear partition between mid-(8000-3000 cal. BP) and late Holocene (last 3000 years) fire regimes. The first period displays remarkable synchrony between sites, consistency with regional fire activity, and with the Holocene Thermal Maximum. These indicate that large-scale controls such as climate (seasonality) promoted or inhibited the occurrence of fire. The late Holocene emphasizes stronger local variability which may be attributed to local human activity,

2) the last 3000 years exhibit a human-controlled fire regime with the onset of permanent agro-pastoral activities. This anthropogenic fire use is heterogeneous between sites in the Lourdes basin, as well as at the Pyrenean scale. Comparison of those last 3000 years of anthropogenic fire regime with the whole Holocene fire history suggests that the perception of humancontrolled fire frequency is depending on the strength of natural control (climate and vegetation).

3) This study provides the first synthesis of fire frequency from individual sites over the Holocene in Europe, at such a high spatial resolution. The results stress the potential of such an approach to supplement and specify regional syntheses of fire activity derived from charcoal accumulation rate in terms of fire regime parameters, and frequency in particular.

\section{Acknowledgments}

This study was funded by the Laboratoire ChronoEnvironnement (CNRS, Université de Franche-Comté) and the ANPYR research program (FEDER/Western Pyrenees National Park) headed by D. Galop. The authors would like to thank Michel Magny for helpful comments on the manuscript, Elise Doyen and Agnes Stock for their help during the field work. David Etienne, Clement Laplaige and Laurent Millet should also be acknowledged for numerous discussions about this research and GIS mapping assistance. The authors express their sincere thanks to Michael Coughlan for his help with the English language. The comments of two anonymous reviewers greatly helped to improve the manuscript.

\section{References}

Ali, A.A., Carcaillet, C., Bergeron, Y., 2009. Long-term fire frequency variability in the eastern Canadian boreal forest: the influences of climate vs. local factors. Global Change Biology 15, 1230-1245.

Alley, R.B., Mayewski, P.A., Sowers, T., Stuiver, M., Taylor, K.C., Clark, P.U., 1997. Holocene climatic instability: a prominent, widespread event 8200 yr ago. Geology 25, 483-486.

Blaauw, M., Van der Plicht, J., Van Geel, B., 2004. Radiocarbon dating of bulk peat samples from raised bogs: non-existence of a previously reported "reservoir effect"? Quaternary Science Reviews 23, 1537-1542.

Blackford, J.J., 2000. Charcoal fragments in surface samples following a fire and the implications for interpretation of subfossil charcoal data. Palaeogeography, Palaeoclimatology, Palaeoecology 164, 33-42.

Buckman, S., Brownlie, K.C., Bourman, R.P., Murray-Wallace, C.V., Morris, R. Lachlan, T.J., Roberts, R.G., Arnold, L.J., Cann, J.H., 2009. Holocene palaeofire records in a high-level, proximal valley-fill (Wilson Bog), Mount Lofty Ranges, South Australia. The Holocene 19, 1017-1029. 
Buffière, D., Faerber, J., Le Caro, P., Metailié, J.-P., 1995. Des « écobuages » aux feux dirigés dans les Pyrénées centrales et occidentales. Revue d'analyse spatiale quantitative et appliquée 32, 103-110.

Buntgen, U., Frank, D., Grudd, H., Esper, J., 2008. Long-term summer temperature variations in the Pyrenees. Climate Dynamics 6, 615-631.

Calvo, E., Grimalt, J., Jansen, E., 2002. High resolution $\mathrm{U}^{\mathrm{K}}{ }_{37}$ sea surface temperature reconstruction in the Norwegian Sea during the Holocene. Quaternary Sciences Reviews 21, 1385-1394.

Carcaillet, C., Bouvier, M., Frechette, B., Larouche, A.C., Richard, P.J.H., 2001. Comparison of pollen slide and sieving methods in lacustrine charcoal analyses for local and regional fire history. The Holocene 11, 467-476.

Carcaillet, C., Ali, A.A., Blarquez, A., Mourier, B., Bremond, L., 2009. Spatial variability of fire history in subalpine forests: from natural to cultural regimes. Ecoscience $16,1-12$.

Clark, J.S., 1988. Particle motion and the theory of charcoal analysis: source area, transport, deposition and sampling. Quaternary Research 30, 67-80.

Clark, J.S., Merkt, I., Muller, H., 1989. Post-Glacial fire, vegetation and human history of the northern Alpine Forelands, southwestern Germany. Journal of Ecology 77, $897-925$.

Clark, J.S., Patterson, W.A., 1997. Background and local charcoal in sediments: scales of fire evidence in the Palaeorecord. In: Clark, J.S., Cachier, H., Goldammer, J.G., Stocks, B. (Eds.), Sediments Records of Biomass Burning and Global Change. NATO ASI Series. Springer, Berlin, pp. 23-49.

Clark, J.S., Royall, P.D., 1996. Local and regional sediment charcoal evidence for fire regimes in presettlement north-eastern North America. Journal of Ecology 84, $365-383$.

Clark, J.S., Lynch, J., Stocks, B.J., Goldammer, J.G., 1998. Relationships between charcoal particles in air and sediments in west-central Siberia. The Holocene 8 , 19-29.

Colombaroli, D., Vannière, B., Chapron, E., Magny, M., Tinner, W., 2008. Fire-vegetation interactions during the Mesolithic-Neolithic transition at Lago dell'Accesa, Tuscany, Italy. The Holocene 18, 679-692.

Conedera, M., Tinner, W., Neff, C., Meurer, M., Dickens, A.F., Krebs, P., 2009. Reconstructing past fire regimes: methods, applications, and relevance to fire management and conservation. Quaternary Science Reviews 5-6, 555-576.

Davis, B.A.S., Brewer, S., 2009. Orbital forcing and role of latitudinal insolation/ temperature gradient. Climate Dynamics 32, 143-165.

Desprat, S., Sánchez-Goñi, M.F., Loutre, M.-F., 2003. Revealing climatic variability of the last three millennia in northwestern Iberia using pollen influx data. Earth and Planetary Science Letters 213, 63-78.

Eckmeier, E., Rösch, M., Ehrmann, O., Schmidt, M.W.I., Schier, W., Gerlach, R., 2007. Conversion of biomass to charcoal and the carbon mass balance from a slash-andburn experiment in a temperate deciduous forest. The Holocene 17, 539-542.

Enache, M.D., Cumming, B.F., 2006. Tracking recorded fires using charcoal morphology from the sedimentary basin of Prosser Lake, British Columbia (Canada). Quaternary Research 65, 282-292.

Fearnside, P.M., Lima de Alencastro Graça, P.M., Alves Rodrigues, F.J., 2001. Burning of Amazonian rainforests: burning efficiency and charcoal formation in forest cleared for cattle pasture near Manaus, Brazil. Forest Ecology and Management 146, 115-128.

Finsinger, W., Tinner, W., van der Knaap, W.O., Amman, B., 2006. The expansion of hazel (Corylus avellana L.) in the southern Alps: a key for understanding its early Holocene history in Europe ? Quaternary Science Reviews 25, 612-631.

Galop, D., Jalut, G., 1994. Differential human impact and vegetation history in two adjacent Pyrenean valleys in the Ariège basin, southern France, from 3000 B.P. to the present. Vegetation History and Archaeobotany 3, 225-244.

Galop, D., Tual, M., Monna, F., Dominik, J., Beyrie, A., Marembert, F., 2001. Cing millénaires de métallurgie en montagne basque. Les apports d'une démarche intégrée alliant palynologie et géochimie isotopique du plomb. Sud-Ouest Européen 11, 3-15.

Galop, D., Vanniere, B., Fontugne, M., 2002. Human activities and fire history since $4500 \mathrm{BC}$ on the northern slope of the Pyrenees: a record from Cuguron (Central Pyrenees, France). In: Thièbault, S. (Ed.), Charcoal Analysis: Methodological Approaches, Palaeological Results and Wood Uses. Proceedings of the Second International Meeting of Anthracology, Paris. BAR International Series, vol. 1063, pp. 43-51.

Galop, D., Carozza, L., Marembert, F., Bal, M.-C., 2007. Activités pastorales et climat durant l'âge du Bronze dans les Pyrénées: l'état de la question à la lumière des données environnementales et archéologiques. In: Richard, H., Magny, M., Mordant, C. (Eds.), Environnements et cultures à l'âge du Bronze en Europe occidentale. Editions du CTHS, pp. 107-119.

Gavin, D., 2001. Estimation of inbuilt age in radiocarbon ages of soil charcoal for fire history studies. Radiocarbon 43, 27-44.

Gavin, D.G., Hu, F.S., Lertzman, K.P., Corbett, P., 2006. Weak climatic control of stand-scale fire history during the late Holocene. Ecology 87, 1722-1732.

Gellatly, A.F., Grove, J.M., Switsur, V.R., 1992. Mid-Holocene glacial activity in the Pyrenees. The Holocene 2, 266-270.

Heegaard, E., Birks, H.J.B., Telford, R.J., 2005. Relationships between calibrated ages and depth in stratigraphical sequences: an estimation procedure by mixedeffect regression. The Holocene 15, 612-618.

Herail, I., Hubschman, I., Jalut, G., 1986. Quaternary glaciation in the French pyrenees. Quaternary Science Reviews 5, 397-402.

Higuera, P.E., Peters, M.E., Brubaker, L.B., Gavin, D.G., 2007. Understanding the origin and analysis of sediment-charcoal records with a simulation model. Quaternary Science Reviews 26, 1790-1809.
Higuera, P.E., Gavin, D.G., Bartlein, P.J., Hallett, D.J., 2010. Peak detection in sediment-charcoal records: impacts of alternative analytical methods on fire-history interpretation. International Journal of Wildland Fire 19, 996-1014.

Hormes, A., Müller, B.U., Schlüchter, C., 2001. The Alps with little ice: evidence for eight Holocene phases of reduced glacier extent in the Central Swiss Alps. The Holocene 11, 255-265.

Innes, J.B., Blackford, J.J., Simmons, I.G., 2004. Testing the integrity of fine spatial resolution palaeoecological records: microcharcoal data from near-duplicate peat profiles from the North York Moors, UK. Palaeogeography, Palaeoclimatology, Palaeoecology 214, 295-307.

Jalut, G., Aubert, S., Galop, D., Fontugne, M., Belet, J.M., 1996. In: Berglund, B.E., Birks, H.J.B., Ralska-Jaziewczowa, M., Wright, H.E. (Eds.), Type Regions F-zg and F-r, the Northern Slope of the Pyrenees. Palaeoecological Events during the Last 15000 years- Regional Syntheses of Palaeoecological Studies of Lakes and Mires in Europe. J. Wiley\&Sons, pp. 612-632.

Jalut, G., Montserrat Marti, J., Fontugne, M., Delibrias, G., Vilaplana, J.M., Julia, R. 1992. Glacial to interglacial vegetation changes in the northern and southern Pyrenees: deglaciation, vegetation cover and chronology. Quaternary Science Reviews 11, 449-480.

Joerin, U.E., Nicolussi, K., Fischer, A., Stocker, T.F., Schlüchter, C., 2008. Holocene optimum events inferred from subglacial sediments at Tschierva Glacier, Eastern Swiss Alps. Quaternary Science Reviews 27, 337-350.

Jouffroy-Bapicot, I., Pulido, M., Baron, S., Galop, D., Monna, F., Lavoie, M., Ploquin, A. Petit, C., de Beaulieu, J.-L., Richard, R., 2007. Environmental impact of early palaeometallurgy: pollen and geochemical analysis. Vegetation History and Archaeobotany 16, 251-258.

Kaland, P.E., 1986. The origin and management of Norwegian coastal heaths as reflected by pollen analysis. In: Behre, K.-E. (Ed.), Anthropogenic Indicators in Pollen Diagrams. A.A. Balkema, Rotterdam, pp. 19-36. 1986.

Kaltenrieder, P., Procacci, G., Vannière, B., Tinner, W., 2010. Postglacial vegetation and fire history of the Euganean Hills (Colli Euganei) as recorded by sedimentary pollen and charcoal series from Lago della Costa (northeastern Italy). The Holocene 20, 679-695.

Kennet, D.J., 2002. Differences in ${ }^{14} \mathrm{C}$ age between stratigraphically associated charcoal and marine shell from the Archaic period site of kilometre 4, southern Peru: old wood or old water? Radiocarbon 44, 53-58.

Long, C.J., Whitlock, C., Bartlein, P.J., Millspaugh, S.H., 1998. A 9000-year fire history from the Oregon Coast Range, based on a high resolution charcoal study. Canadian Journal of Forest Research 28, 774-787.

Long, C.J., Whitlock, C., Bartlein, P.J., 2007. Holocene vegetation and fire history of the Coast Range, USA. The Holocene 17, 917-926.

Lynch, J.A., Clark, J.S., Stocks, B.J., 2004. Charcoal production, dispersal and deposition from the Fort Providence experimental fire: interpreting fire regimes charcoal records in the boreal forests. Canadian Journal of Forest Research 34, 1642-1656.

Magny, M., 2004. Holocene climate variability as reflected by mid-European lakelevel fluctuations an its probable impact on prehistoric human settlements. Quaternary International 113, 65-79.

Magny, M., Peyron, O., Gauthier, E., Rouè̀che, Y., Bordon, A., Billaud, Y., Chapron, E., Marguet, A., Pétrequin, P., Vannière, B., 2009. Quantitative reconstruction of climatic variations during the Bronze Age based on pollen and lake-level data in the NW Alps, France. Quaternary International 200, 102-110.

Mardones, M., Jalut, G., 1983. La tourbière de Biscaye (alt. 409m, Hautes-Pyrénées): approche paléoécologique des 45000 dernières années. Pollen et Spores 25 (2), 163-212.

Marlon, J.R., Bartlein, P.J., Carcaillet, C., Gavin, D.G., Harrison, S.P., Higuera, P.E., Joos, F., Power, M.J., Prentice, I.C., 2008. Climate and human influences on global biomass burning over the past two millennia. Nature Geoscience. doi:10.1038/ ngeo313.

Miras, Y., Ejarque, A., Riera, S., Palet, J.M., Orengo, H., Euba, I., 2007. In: Palevol, C.R. (Ed.), Dynamique holocène de la végétation et occupation des Pyrénées andorranes depuis le Néolithique ancien, d'après l'analyse pollinique de la tourbière de Bosc dels Estanyons (2180m Vall de Madriu, Andorre), vol. 6, pp 291-300.

Millet, L., Arnaud, F., Heiri, O., Magny, M., Verneaux, V., Desmet, M., 2009. LateHolocene summer temperature reconstruction from chironomid assemblages of Lake Anterne, northern French Alps. The Holocene 19, 317-328.

Monna, F., Galop, D., Carozza, L., Tual, M., Beyrie, A., Marembert, F., Chateau, C., Dominik, J., Grousset, F.E., 2004. Environmental impact of Basque mining and smelting recorded in a high ash minerogenic peat deposit. Science of the Tota Environment 327, 197-214.

Morellón, M., Valero-Garcés, B., González-Sampériz, P., Vegas-Vilarrúbia, T, Rubio, E., Rieradevall, M., Delgado-Huertas, A., Mata, P., Romero, Ó, Engstrom, D. R., López-Vicente, M., Navas, A., Soto, J. Climate changes and human activities recorded in the sediments of Lake Estanya (NE Spain) during the Medieval Warm Period and Little Ice Age. Journal of Paleolimnology, in press, doi: 10.1007/s10933-009-9346-3.

Nicolussi, K., Kaufmann, M., Melvin, T.M., van der Plicht, J., Schießling, P., Thurner, A., 2009. A 9111 year long conifer tree-ring chronology for the European Alps: a base for environmental and climatic investigations. The Holocene 19, 909-920.

Ohlson, M., Tryterud, E., 2000. Interpretation of the charcoal record in forest soils: forest fires and their production and deposition of macroscopic charcoal. The Holocene 10, 519-525. 
Olsson, F., Gaillard, M.-I., Lemdahl, G., Greisman, A., Lanos, P., Marguerie, D. Marcoux, N., Skoglund, P., Wäglind, J., 2010. A continuous record of fire covering the last 10500 calendar years from southern Sweden - The role of climate and human activities. Palaeogeography, Palaeoclimatology, Palaeoecology 291, 128-141.

Oswald, W.W., Anderson, P.M., Brown, T.A., Brubaker, L.B., Hu, F.S., Lozhkin, A.V., Tinner, W., Kaltenrieder, P., 2005. Effects of sample mass and macrofossil type on radiocarbon dating of arctic and boreal lake sediments. The Holocene 15, 758-767.

Pallàs, R., Rodés, A., Braucher, R., Carcaillet, J., Ortuño, M., Bordonau, J., Bourlès, D. Vilaplana, J.M., Masana, E., Santanach, P., 2006. Late Pleistocene and Holocene glaciation in the Pyrenees: a critical review and new evidence from ${ }^{10} \mathrm{Be}$ exposure ages, south-central Pyrenees. Quaternary Science Reviews 28, 2937-2963.

Pèlachs, A., Nadal, J., Soriano, J.M., Molina, D., Cunill, R., 2009. Changes in Pyrenean woodlands as a result of the intensity of human exploitation: 2,000 years of metallurgy in Vallferrera, northeast Iberian Peninsula. Vegetation History and Archaeobotany 18, 403-416.

Peñalba, C., Arnold, M., Guiot, J., Duplessy, J., de Baulieu, J.-L., 1997. Termination of the Last Glaciation in the Iberian Peninsula Inferred from the Pollen Sequence of Quintanar de la Sierra. Quaternary Research 48, 205-214.

Peters, M.E., Higuera, P.E., 2007. Quantifying the source area of macroscopic charcoal with a particle dispersal model. Quaternary Research 67, 304-310.

Pisaric, M.F.J., 2002. Long-distance transport of terrestrial plant material by convection resulting from forest fires. Journal of Palaeolimnology 28, 349-354.

Power, M.J., Marlon, J., Ortiz, N., Bartlein, P.J., Harrison, S.P., Mayle, F.E., Ballouche, A. Bradshaw, R.H.W., Carcaillet, C., Cordova, C., Mooney, S., Moreno, P.I., Prentice, I.C., Thonicke, K., Tinner, W., Whitlock, C., Zhang, Y., Zhao, Y., Ali, A.A. Anderson, R.S., Beer, R., Behling, H., Briles, C., Brown, K.J., Brunelle, A., Bush, M., Camill, P., Chu, G.Q., Clark, J., Colombaroli, D., Connor, S., Daniau, A.-L., Daniels, M., Dodson, J., Doughty, E., Edwards, M.E., Finsinger, W., Foster, D., Frechette, J., Gaillard, M.-J., Gavin, D.G., Gobet, E., Haberle, S., Hallett, D.J., Higuera, P., Hope, G., Horn, S., Inoue, J., Kaltenrieder, P., Kennedy, L., Kong, Z.C., Larsen, C., Long, C.J., Lynch, J., Lynch, E.A., McGlone, M., Meeks, S., Mensing, S. Meyer, G., Minckley, T., Mohr, I., Nelson, D.M., New, I., Newnham, R., Noti, R. Oswald, W., Pierce, J., Richard, P.J.H., Rowe, C., Sanchez-Goni, M.F., Shuman, B.N., Takahara, H., Toney, J., Turney, C., Urrego-Sanchez, D.H., Umbanhowar, C., Vandergoes, M., Vannière, B., Vescovi, E., Walsh, M., Wang, X., Williams, N. Wilmshurst, J., Zhang, J.H., 2008. Changes in fire regimes since the Last Glacial Maximum: an assessment based on a global synthesis and analysis of charcoa data. Climate Dynamics 30, 887-907.

Préfecture des Hautes-Pyrénées, 2007. Plan départemental de Protection des Forêts Contre les Incendies (PPFCI), 58p. http://www.risquesmajeurs-hautes-pyrenees. pref.gouv.fr/.

R Development Core Team, 2009. R: a Language and Environment for Statistical Computing. R Fondation for Statistical Computing, Vienna, Austria. http://www. R-projetc.org.

Reille, M., Andrieu, V., 1995. Late-Pleistocene and holocene in the Lourdes basin (western pyrenees, France): new pollenanalytical and chronological data. Vegetation History and Archaeobotany 4, 1-21.
Reimer, P.J., Baillie, M.G.L., Bard, E., Bayliss, A., Beck, J.W., Blackwell, P.G., Bronk Ramsey, C., Buck, C.E., Burr, G.S., Edwards, R.L., Friedrich, M., Grootes, P.M., Guilderson, T.P., Hajdas, I., Heaton, T.J., Hogg, A.G., Hughen, K.A., Kaiser, K.F. Kromer, B., McCormac, F.G., Manning, S.W., Reimer, R.W., Richards, D.A., Southon, J.R., Talamo, S., Turney, C.S.M., van der Plicht, J., Weyhenmeyer, C.E., 2009. IntCal09 and Marine09 radiocarbon age calibration curves, $0-50,000$ years cal BP. Radiocarbon 51 (4), 1111-1150.

Renssen, H., Seppä, H., Heiri, O., Roche, D.M., Goosse, H., Fichefet, T., 2009. The spatial and temporal complexity of the Holocene thermal maximum. Nature Geoscience 2, 411-414.

Rhodes, A.N., 1998. A method for the preparation and quantification of microscopic charcoal from terrestrial and lacustrine sediment cores. The Holocene 8,113-117.

Ribet N., 2009. Parcours du feu. Techniques de brûlage à feu courant et socialisation de la nature dans les Monts d'Auvergne et les Pyrénées centrales. Thèse de Doctorat, EHESS Paris.

Rius, D., Vannière, B., Galop, D., 2009. Fire frequency and landscape management in the north-western Pyrenean piedmont (France) since the early Neolithic (8000 cal. BP). The Holocene 19 (6), 847-859.

Stuiver, M., Reimer, P.J., 1993. Extended 14C data base and revised CALIB 3.0 14C age calibration program. Radiocarbon 35, 215-230.

Tinner, W., Ammann, B., 2001. Timberline paleoecology in the Alps. PAGES News 9, 9-11.

Tinner, W., Conedera, M., Ammann, B., Lotter, A.F., 2005. Fire ecology north and south of the Alps since the last ice age. The Holocene 15, 1214-1226.

Tinner, W., Hofstetter, S., Zeugin, F., Conedera, M., Wohlgemuth, T., Zimmermann, L., Zweifel, R., 2006. Long-distance transport of macroscopic charcoal by an intensive crown fire in the Swiss Alps - implications for fire history reconstruction. The Holocene 16, 287-292.

Umbanhowar, C.E., McGrath, M.J., 1998. Experimental production and analysis of microscopic charcoal from wood, leaves and grasses. The Holocene 8, 341-346.

Vannière, B., Colombaroli, D., Roberts, N., 2010. A fire paradox around the Mediterranean. PAGES Newsletter 18 (2), 63-65.

Vannière, B., Galop, D., Rendu, C., Davasse, B., 2001. Feu et pratiques agro-pastorales dans les Pyrénées-Orientales: le cas de la montagne d'Enveitg (Cerdagne, Pyrénées-Orientales, France). Revue Géographique des Pyrénées et du Sud Ouest 11, 29-42.

Vannière, B., Power, M.J., Roberts, N., Tinner, W., Carrión, J., Magny, M., Bartlein, P., Colombaroli, D., Daniau, A.-L., Finsinger, W., Gil-Romera, G., Kaltenrieder, P., Magri, D., Pini, R., Sadori, L., Turner, R., Valsecchi, V., Vescovi, E., 2011. CircumMediterranean fire activity and climate changes during the mid-Holocene environmental transition (8500-2500 cal. BP). The Holocene 21, 53-73.

Whitlock, C., Larsen, C., 2001. Charcoal as a fire proxy. In: Smol, J.P., Birks, H.J.B., Last, W.M. (Eds.), Tracking Environmental Change Using Lake Sediments. Terrestrial, Algal and Siliceous Indicators. Kluwer, Dordrecht, pp. 75-97.

Whitlock, C., Millspaugh, S.H., 1996. Testing the assumptions of fire-history studies: an examination of modern charcoal accumulation in Yellowstone National Park, USA. The Holocene 6, 7-15. 